Research Article/Araştırma Makalesi

\title{
What Do Pre-Service Mathematics Teachers Think about Context- Based Learning? A Qualitative Study
}

\author{
Mustafa OBAY *1 (D) Halil Coşkun ÇELİK 2 (iD) \\ ${ }^{1}$ Siirt University, Education Faculty, Siirt, Turkey, mustafaobay@gmail.com \\ 2 Siirt University, Education Faculty, Siirt, Turkey, hcoskun.celik@gmail.com \\ * Corresponding Author: hcoskun.celik@gmail.com
}

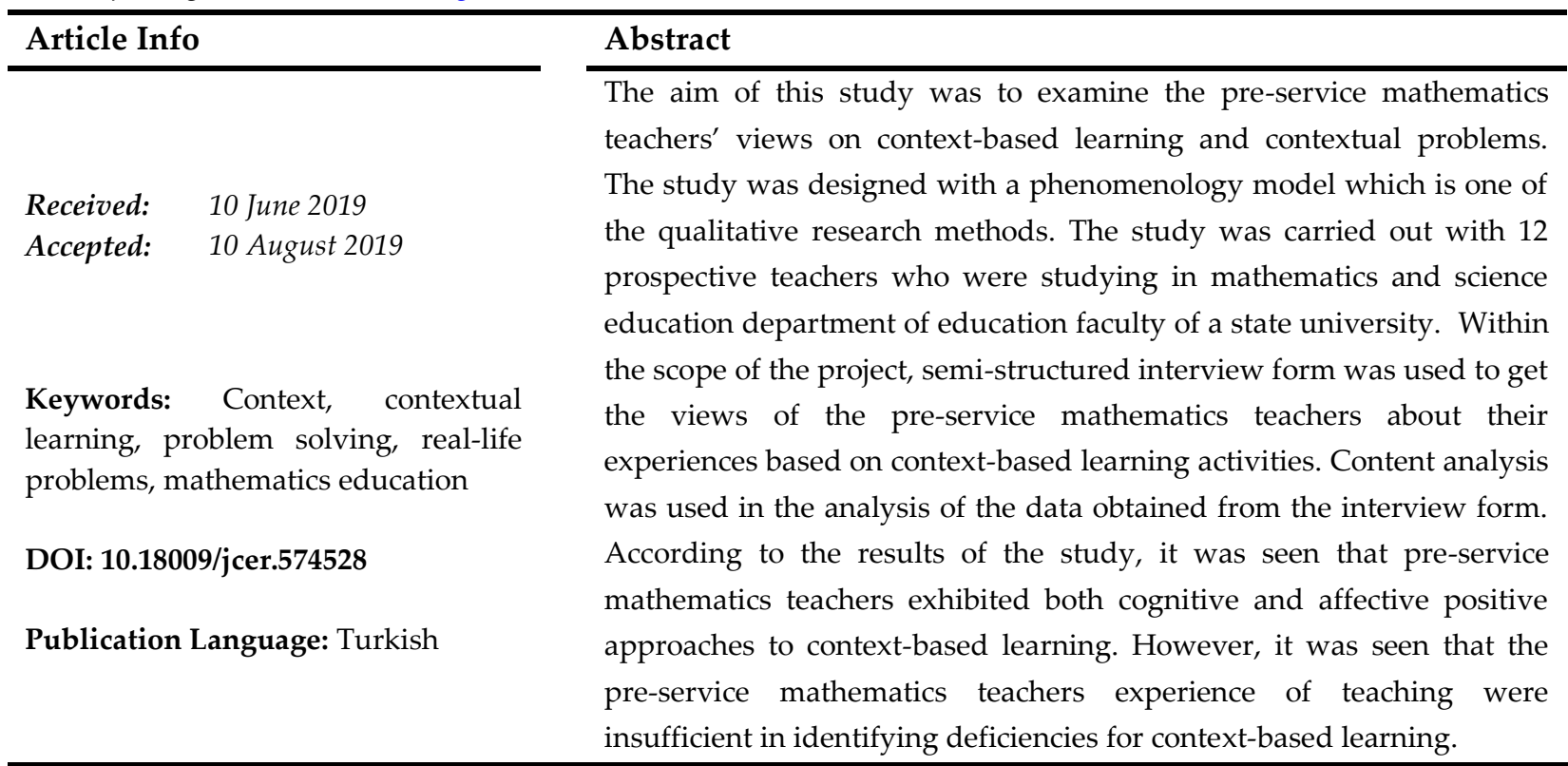

open access Crossmark (c)

To cite this article: Obay, M. \& Çelik, H.C. (2019). İlköğretim matematik öğretmen adayları bağlam temelli öğrenme hakkında ne düşünüyor? Nitel bir araştırma. Journal of Computer and Education Research, 7 (14), 284-313. DOI: 10.18009/jcer.574528

\section{İlköğretim Matematik Öğretmen Adayları Bağlam Temelli Öğrenme Hakkında Ne Düşünüyor? Nitel Bir Araştırma}

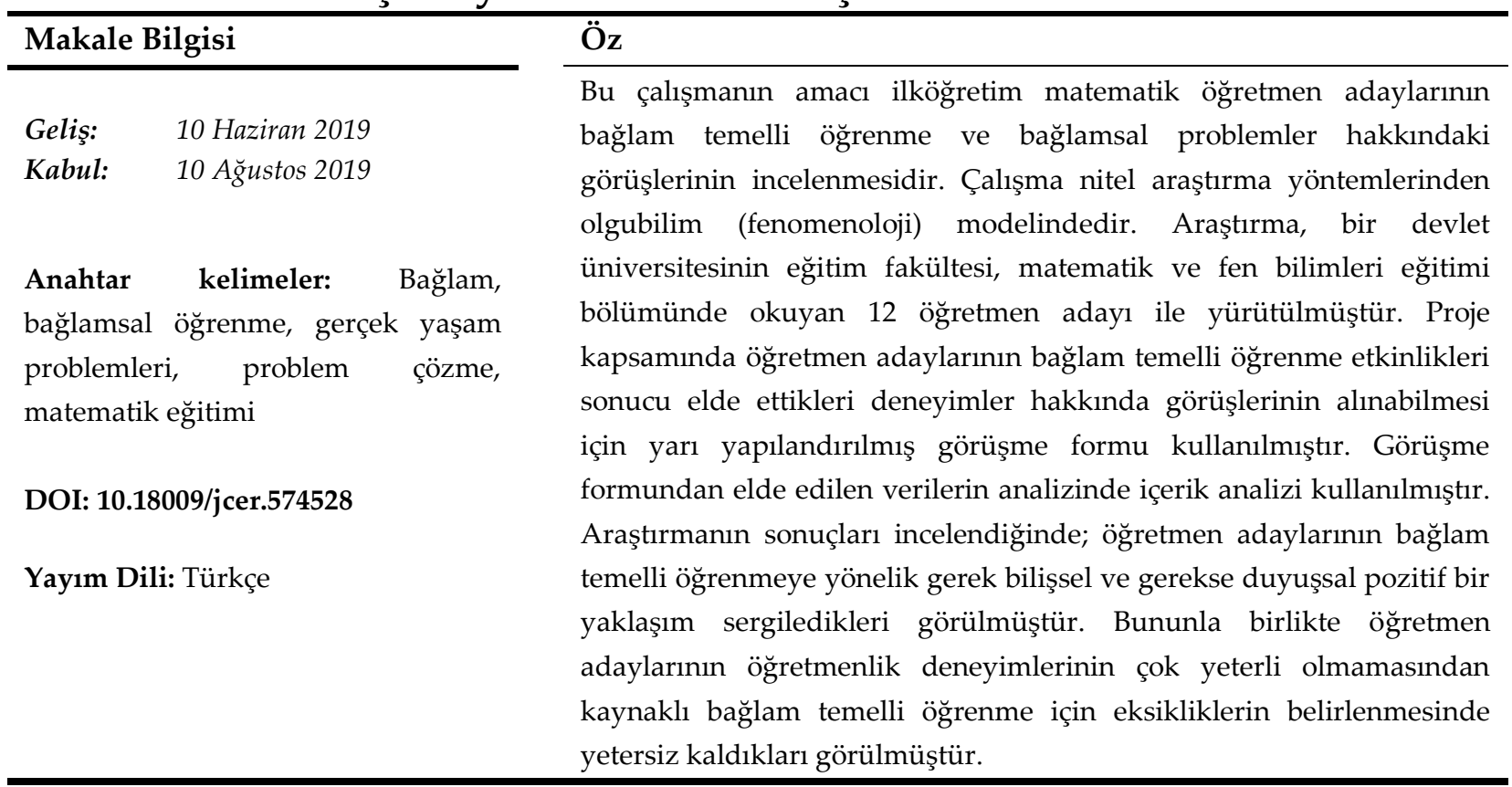




\section{Summary}

\section{What Do Pre-Service Mathematics Teachers Think about Context- Based Learning? A Qualitative Study}

\section{Introduction}

Real-life situations are increasingly used in mathematics education, the new mathematics curriculum in Turkey; it is observed that increasing prevalence of innovative teaching and learning strategies. Most of these strategies not only increase students' learning, but also give them specific learning habits that will provide lifelong benefits and enable them to actively participate in learning. Context-based learning is one of these teaching strategies. This learning and teaching strategy encourage students to hold responsibility for their own learning and to relate knowledge and practice to various contexts of their lives (Satriani, Emilia \& Gunawan, 2012). It also allows students to find out how and why they will use the new knowledge and skills they have learned (Şensoy \& Gökçe, 2017). Context-based learning involves the process of creating a student-driven hypothesis that leads to a scenario for students and ultimately leads to the development of their own learning needs (Trimmer, Laracy \& Love-Gray, 2009). In the context-based learning process, students are motivated to acquire and view knowledge as they are engaged in solving a particular-problem or a different reality (Rose, 2012; Widjaja, 2013). The main feature of a good context-based mathematical problem is that it opens the door to different interpretation and solution strategies (Widjaja, 2013). In context-based problems; 1) an appropriate context, 2) directly related to real life, 3) a scenario in which the student will be involved, 4) openness to use mental skills (at least to be comprehended), 5) It should be felt that it should be terminated with a qualitative question sentence and this should be proved quantitatively (Tekbiyık \& Akdeniz, 2010).

The aim of this study is to examine the pre-service mathematics teachers' approaches to context-based learning and their views on contextual problems. For this purpose, it includes the cognitive and affective approaches of pre-service mathematics teachers of 
context-based instruction. At the same time, it has been examined how pre-service mathematics teachers' attitudes towards mathematics and contextual problem-solving change.

\section{Method}

This research is a qualitative study. In this study, phenomenology model was preferred to examine the pre-service teachers' views on context-based learning and contextual problems. The participants of the study are 12 pre-service mathematics teachers who are studying in the faculty of education, mathematics and science education department of a state university. These pre-service mathematics teachers are also those who voluntarily participate in the project related to context-based learning and contextual problems accepted within the scope of Scientific Research Projects and participate in the context-based material design within this project. Content analysis was used in the analysis of the data obtained from the research.

\section{Results}

Pre-service mathematics teachers stated that they mathematized a set of daily life interactions. It was observed that they mainly focused on the association phenomenon. The correlation was found to be essentially the overlap between the knowledge in the minds of pre-service mathematics teachers and the objective world. In this case, it is seen that it mainly refers to the mental and mathematical transformation of objective world materials. It was seen that pre-service mathematics teachers attach importance to concretization in mathematics learning, this situation has some positive aspects on learning, and it is stated that the concretization for learning leads to easy reasoning. They also stated that it is easy to think on concrete material in the problem-solving process and this leads to easier thinking.

On the other hand, they stated that easier reasoning depends on concrete thinking, and concrete thinking-based approach leads to meaningful and easier learning, because this situation leads to learning related to daily life. At the same time, it is stated that the use of material makes it easier to see some information because it is also interesting to use material. It has been seen that pre-service mathematics teachers see some difficulties in contextual learning and this is more difficult to reduce. They showed positive attitudes towards using context-based learning in their profession life. In particular, affirmation, association with 
daily life, anxiety reduction and permanent learning lead to expressions that show that teacher candidates have a positive approach to why they will use context-based learning.

\section{Discussion and Conclusion}

One of the most challenging subjects of mathematics learning groups is the concretization of some numerical processes in mind. One mistake that teachers often make is that learners ignore the difficulties they face. Contextual learning, like other theories that make use of concrete conditions in learning, provides this opportunity to learners. Preservice mathematics teachers explained the benefits of concretization in mathematics courses based on context-based learning. Context-based learning makes the process of reasoning easier because learning is associated with real life. In addition, they bear the idea that when the situation expressed in the concretization phase of the numerical processes, that is, concretization and easy reasoning is not realized the application of some operational information remains. It is seen that the they have a facilitation approach to the problem of thinking in mathematics education in terms of benefiting from problem solving stages while solving context-based problems. On the other hand, they stated that the concrete thinking process makes problem solving meaningful and easier and brings it to a level that can be associated with daily life. At the same time, they have a positive attitude towards contextbased learning. This leads them to create a positive expectation for context-based learning that they will use this method in the teaching profession.

One of the remarkable factors in this study is the inexperience of pre-service mathematics teachers. Similarly, it is thought that conducting a study with active teachers will provide important results. In addition, the extent to which middle school students use mathematics called street mathematics in daily life can be an important research topic. In addition to this, although pre-service mathematics teachers show positive attitudes towards context-based learning, it is thought to be useful to evaluate their knowledge, attitudes and perceptions with a qualitative approach in the courses about problem solving they take in the university to identify the missing aspects of this learning method. 


\section{Giriş}

Matematikte soyut kavramların günlük yaşamdaki bağlamlarla ilişkilendirilmesi öğrencilerin matematik başarılarını, ilgilerini (Özkan \& Selçuk, 2017), matematik öğrenme motivasyonlarını arttırır, daha zengin, etkili ve eğlenceli öğrenme ortamlarının oluşmasını sağlar. Böylece öğrencilerin günlük yaşamlarında karşılaştıkları problemler ile matematiği ilişkilendirme konusunda farkındalık düzeyleri artar ve problemlerin çözümleri için geliştirebilecekleri farklı çözüm yaklaşımları sayesinde akademik başarıları gelişir. Bu, sınıfta öğrenme ve öğretme sürecinin gerçek dünyaya bağlı olması gerektiği anlamına gelir. Matematikte gerçek yaşam durumlarının giderek daha fazla kullanıldığı, buna paralel olarak Türkiye'de yeni matematik öğretim programlarında, yenilikçi öğrenme ve öğretme stratejilerinin yaygın bir şekilde kullanılmasına önem verildiği görülmektedir. $\mathrm{Bu}$ stratejilerin çoğu, öğrencilerin yalnızca öğrenmelerini arttırmak için değil, onlara hem yaşam boyu fayda sağlayacak belirli öğrenme alışkanlıklarını kazandırmakta hem de aktif olarak öğrenmeye katılmalarını sağlamaktadır. Bağlam temelli öğrenme (veya bağlamsal öğrenme) bu öğretim stratejilerinden birisidir (Shiu-Sing, 2005).

Bağlam temelli öğrenme, günlük yaşamda karşılaşılan problemlerden yola çıkarak, öğrenilen bilgileri ihtiyaç haline getiren böylece bilimsel kavram ve ilişkileri bu olay ve sorunların çözümünde araç olarak kullanmayı amaçlar (Acar \& Yaman, 2011). Bir öğrenme ve öğretme yaklaşımı olan bağlam temelli öğrenme öğrencileri kendi öğrenmelerinden sorumlu tutmaya ve bilgi ile uygulaması arasında yaşamlarının çeşitli bağlamlarıyla ilişki kurmaya teşvik eder (Satriani, Emilia \& Gunawan, 2012). Ayrıca bağlam temelli öğrenme, öğrencilerin gerçek yaşamları arasında bağlantı kurmaları konusunda aktif katılımlarını destekler ve onları motive eder (Coştu, 2009, Yam, 2005). Öğrencilerin yeni öğrendikleri bilgi ve becerileri nasıl ve niçin kullanacaklarına cevap bulmalarını sağlar (Şensoy \& Gökçe, 2017). Bağlam temelli öğrenmenin ardındaki mantık teorinin pratik deneyim ile bütünleşmesine dayanır, ancak pratik deneyim belirli insanlara, zamana ve yere bağlı olduğundan, öğretim tekniklerinin etkili olması için mutlaka çeşitlendirilmeleri gerekmektedir (Young, 2005).

Bağlam temelli öğrenme süreci, öğrencilere bir senaryo sunulmasını ve nihayetinde öğrencilerin kendi öğrenme ihtiyaçlarının geliştirilmesine yol açan, öğrenci tarafından yönlendirilen bir hipotez oluşturma sürecini kapsar (Trimmer, Laracy, \& Love-Gray, 2009). 
Rose'a (2012) göre bağlam temelli öğrenme süreci şu aşamaları içermelidir. İlk olarak, öğrenci önceki bilgiyi yeni bilgileriyle bütünleştiren gerçek deneyime veya etkileşimli tartışmaya katılır. İkincisi, öğrenci öğrenilen görevleri tamamlayarak bir veya daha fazla akademik disiplinden elde edilen kavramları ve teorik bilgileri anlamlaştırır. Üçüncüsü, öğrenci gerçek, somut problemleri çözmek veya etkinlikteki bilgiyi göstermek için kavramsal ve teorik bilgileri kullanır. Son olarak, bulgular ve sonuçlar çeşitli şekillerde üretilir ve raporlanır.

\section{Bağlam Temelli Problem}

Problem, kişinin çözme isteği duyduğu ve çözüm yöntemi konusunda hazırlıksız olduğu ancak kişinin mevcut bilgi ve deneyimlerini kullanarak çözümü bulmak adına bir girişim geliştirdiği durumdur (Olkun \& Uçar, 2012). Matematik problemi çözme; basit sözel problemleri ve rutin olmayan problemleri çözmeyi, matematiği gerçek yaşam durumlarında uygulamayı ve yeni alanların oluşmasına neden olabilecek yorumları yapmayı ve test etmeyi kapsar (Silver, Brancha, \& Adams, 1980; Akt. Baki, 2018). Bağlam temelli öğrenme, öğrencilerin problem çözme sürecini tamamlamalarında etkili bir stratejidir (Yu, Fan \& Lin, 2014). Bağlam temelli öğrenmede, öğrenciler belirli bir problemi çözme veya farklı bir realiteyle meşgul oldukları için, bilgiyi edinmeye ve değerli olarak görmeye motive olurlar (Rose, 2012; Widjaja, 2013).

Bağlam temelli öğrenmenin literatüre girmesiyle birlikte bağlam temelli problem kavramı ön plana çıkmıştır. Matematik öğretimindeki amaçları açısından problemler; sıradan (rutin) problemler ve sıra dişı (rutin olmayan) problemler olarak sinıflandırılmaktadır (Altun, 2011; Yenilmez, 2010). Rutin problemler matematik ders kitaplarında sıklıkla yer verilen ve dört işlem problemleri olarak bilinen problemlerdir. Rutin olmayan problemler ise öğrencilerin çok karşılaşmadığı ve rutin problemlerin aksine dört işlem becerilerinin ötesinde, verileri organize etme, sınıflandırma, ilişkileri görme gibi üst düzey becerilere sahip olmayı ve birtakım aktivitelere arka arkaya yapmayı gerektirmektedir (Souviney, 1989). Bu problemler gerçek yaşamda karşılaşılmış ya da karşılaşılabilecek bir durumun ifadesi olduklarından dolayı gerçek hayat problemleri olarak bilinir (Altun, 2011). Dolayısıyla bağlam temelli problemler rutin olmayan gerçek hayat problemleriyle benzer anlamda düşünülmektedir. Bağlamsal bilgi, gerçek dünyadaki günlük yaşam problemleriyle ilgilidir ve problemin kendi hikâyesiyle bir bağlamda sunulması yoluyla öğrenme ortamındaki yerini alır (Saenz, 2009). İyi bir bağlam temelli matematik probleminin temel 
özelliği, farklı yorum ve çözüm stratejilerine kapı aralamasıdır (Widjaja, 2013). Bağlam temelli problemler için, 1) uygun bir bağlam, 2) gerçek yaşamla doğrudan ilişkili, 3) öğrencinin içinde yer alacağı bir senaryo, 4) zihinsel becerileri kullanmaya açıklık (en azından anlama düzeyinde olması), 5) nitel bir soru cümlesiyle sonlandırılması ve bunun nicel olarak ispatlanması gerektiği hissettirilmelidir (Tekbıyık \& Akdeniz, 2010).

Öğrencilere sunulan problemler, farklı bağlamlarda geliştirilen yeni matematiksel bilgileri uygulamak veya bağlamsallaşmış bir durumda yeni matematiksel bilgileri geliştirmek için bir araç olabilirler (Savard \& Polotskaia 2017). Ancak bağlamsal problemler kendi başlarına öğrenciler için anlamlı bir öğrenmeye katkıda bulunmayabilir. Bu süreçte öğretmenlerin ve öğretmen adaylarının, temel matematiksel fikirler için bağlamı yorumlamalarında öğrencilerin ilgisini çekmesi önemli görülmektedir (Widjaja, 2013).

Etkili bağlam temelli bir eğitim oluşturabilmek, öğretmenlerin sınıf kültürünü değiştirmeleriyle sağlanabilir (Cobb \& Yackel, 1998). Yam (2005) bağlam temelli öğrenmeye dayalı işlenen derslerde dikkat edilmesi gereken bazı ilkeler belirlemiştir. Bu ilkeler özetle a) problem çözmeyi vurgulamak, b) sosyal dünya ile ilişkilendirme ve farkındalık c) özdüzenleme, d) öğretmeyi, farklı yaşam bağlamlarıyla ilişkili hale getirme, e) işbirlikçi öğrenme konusunda cesaretlendirme, f) alternatif ölçme ve değerlendirme yöntemlerinin kullanılması.

Bağlamların matematiğin gerçek yaşamda uygulanmasına verilen önem (Vidic, 2015) giderek artmaktadır. Bağlam temelli öğrenmeye yönelik eğilim, ilköğretimden üniversiteye kadar tüm yaş gruplarında (Köse \& Tosun, 2015) ve tüm eğitimciler tarafından giderek artan bir şekilde kabul görmektedir. Bağlam temelli öğrenme, yetişkin öğrenciler için uygun ve çok etkili bir öğrenme stratejisi olabilmektedir (Choi \& Johnson, 2005). Bağlam temelli öğrenmenin gerçekleştirilebilmesi, öğretim programlarının, öğrenme etkinlikleri ve öğrenme adımlarıyla birlikte uygulanmasına bağlıdır (Parchmann ve ark., 2006). Bağlam temelli öğrenme, yapılandırmacı öğrenme teorileri ve kavramsal değişim çerçevelerini dikkate alır (Parchmann, Broman, Busker \& Rudnik, 2015). Bağlam temelli öğrenmenin, gerçek dünya durumları ile bağlantılı olması gereklidir. Bu bağlam, öğrencilerin sembolik öğrenme içeriğini gerçek dünyadaki referanslarıyla ilişkilendirebilmelerini sağlar (Westera, 2011). Bu tür referans çerçevesi, bireyin bugüne kadar olan gerçek dünya deneyimleri ve etkileşimleriyle desteklenir (Kleden \& Geradus, 2018). 
Yapılan çalışmalar, bağlam temelli öğrenmenin akademik başarıya etkisi, bağlamsal problemleri çözmede karşılaşılan zorluklar, bağlam temelli problemlere olan ilgi, motivasyon ve bağlam temelli problem çözme üzerine yoğunlaşmıştır. Öğretmen adaylarının bağlam temelli öğrenme konusunda bazı bilgi ve uygulama eksikliklerinin olduğu ve bu durumun üniversite düzeyindeki derslerde bağlam temelli öğrenme etkinliklerinin kullanılarak geliştirilmesi gerektiği belirtilmiştir (Özcan \& Gerçek, 2015). Widjaja (2013) öğrencilerin bağlamsal problemleri çözmede karşılaştıkları zorlukları rapor etmiştir. Saenz (2009) öğretmen adaylarının bağlamsal problemlerde, kavramsal ve işlemsel olanlara göre daha çok güçlük çektiğini belirtmiştir. Vidic (2015) çalışmasında, üniversite öğrencilerinin uygulanan bir sınavda bağlam temelli problemleri çözmede başarısız oldukları sonucuna ulaşmıştır. Benzer çalışmalarda, ortaokul öğrencilerinin \%75'inin bağlamsal matematik problemlerini tam olarak çözemediği/tamamlayamadıkları (Lutfianto ve diğ., 2013), rutin olmayan problemlerin çözümünde başarı düzeylerinin düşük olduğu vurgulanmıştır (Gök \& Erdoğan, 2017). Ayrıca, 5. sınıf öğrencileri üzerinde yapılan çalışmalarda, öğrencilerin sayısal problemlere (bağlamsal olmayan) ilişkin problem çözme performanslarının, bağlamsal problemlerden daha iyi olduğu bulunmuştur (Yang \& Liu, 2013; Wyndhamn \& Säljö, 1997).

Yang (2006), Yang ve Wu (2010) matematik öğrenme ile bağlantılı olarak gerçekçi yaşam durumlarının ortaya konması gerektiğini belirtmişlerdir. Wernet (2015) öğrencilerin bağlamsal olmayan problemlerden ziyade bağlamsal problemlere daha çok ilgi duyduklarını rapor etmiştir. Diğer bir çalışmada ise öğrencilerin gerçek hayat problemlerine yakın temsili problemlerde daha iyi performans sergiledikleri (Hoogland ve diğ., 2018), bağlamsal öğrenmenin matematik öğrenme çıktılarını iyileştirmede (Becher \& Selter, 1996), motivasyonu arttırmada, yaratıcılığı geliştirmede ve aktivite yapmaya teşvik etmede önemli etkilerinin olduğu rapor edilmiştir (Hadi, 2002). Bağlam temelli öğrenme üniversite düzeyindeki öğrencilerin ilgi ve motivasyonu üzerinde pozitif etki göstermektedir (Parchmann ve diğ., 2015). Holman ve Pilling (2004) bağlam temelli öğrenmenin geleneksel öğrenmeye göre öğrencilerin ilgisini arttırmada daha başarılı olabildiğini savunmaktadırlar. Başka bir çalışmada, geleneksel öğretime göre bağlamsal öğrenme, öğrencilerin öğrenme çıktılarını kavramsal anlama biçiminde geliştirdiği ve özellikle problem çözme yeteneklerini pozitif yönde etkilediği belirtilmiştir (Jazuli, Sulthon \& Kuswandi, 2017). Özkan ve Selçuk (2017) ortaokul öğrencileri üzerinde yaptıkları çalışmada benzer sonuçlar elde etmişlerdir. 
Tural (2012) çalışmasında, öğretmen adaylarının geleneksel problemlere alışkın olmalarına rağmen bağlam temelli problem geliştirme kriterlerine uygun problemler geliştirebildiklerini, ancak bağlam temelli problem geliştirme sürecinde "Problem nitel bir soru cümlesiyle sonlandırılmalıdır, ancak bunun nicel olarak ispatlanması gerektiği okuyucuya hissettirilmelidir" kriterini çok dikkate almadıklarını belirlemiştir.

Öğretim programlarında yer alan kazanımlara yönelik gerçek yaşamla ilişki kurmayı destekleyen öğretim materyallerine ihtiyaç duyulmaktadır (Shiu-Sing, 2005). Demircioğlu (2008) bağlam temelli geliştirilen materyalin öğretmen adaylarının alternatif fikirlerini bilimsel anlamalara dönüştürmede etkili olduğunu, kavramların anlamlı öğrenilmesini sağlayarak kalıcılığı artırdığı ve öğrenilen kavramların zihinde yapılandırılma işleminin öğretimden sonra da devam etmesine önemli katkılar sağladığını, motivasyon ve tutumlarını da pozitif yönde etkilediğini belirtmiştir. Değermenci (2009) bağlam temelli geliştirdiği materyalin uygunluğunu öğretmen ve öğrencilerle yaptığı mülakatlar ve sınıfta ortamındaki gözlemlerle değerlendirmiş, öğrencilerin ve öğretmenlerin bağlam temelli öğrenmeyi tam olarak algılayamadıklarını saptamıştır.

\section{Araştırmanın Amacı}

$\mathrm{Bu}$ araştırmanın amacı matematik öğretmen adaylarının bağlam temelli öğrenmeye yaklaşımlarının ve bağlamsal problemler hakkındaki görüşlerinin irdelenmesidir. Bu amaçla bağlam temelli öğretimin öğretmen adaylarının konuya yönelik bilişsel ve duyuşsal yaklaşımlarını kapsamaktadır. Öğretmen adaylarının aynı zamanda matematiğe karşı ve bağlamsal problem çözmeye karşı tutumlarının nasıl değiştiği de ayrıca incelenmek istenmiştir. Bu amaca bağlı olarak araştırmanın esas problemini; öğretmen adaylarının bağlam temelli öğrenmeye yönelik tutum ve düşünceleri nelerdir? Sorusu teşkil etmektedir.

$\mathrm{Bu}$ araştırmada öğretmen adaylarının bağlam temelli öğrenme ve bağlamsal problemler hakkındaki görüşlerinin ortaya konması amaçlanmıştır. Özellikle Milli Eğitim Bakanlığı (MEB) 2009 programı göz önüne alındığında ilköğretim öğrencilerine yönelik başlatılan yeni müfredat gereği farklı bağlam ve koşullarda problem çözme becerilerinin gelişimine verilen önem, bu çalışma için temel teşkil etmektedir. Ülkemizin matematik problem çözme düzeyinde diğer uluslarla girmiş olduğu rekabette istenilen düzeyi yakalayabilmesi açısından farklı yöntem ve tekniklerin denenmesi ve bu deneyimlerden elde edilen sonuçların titizlikle değerlendirilmesini gerektirmektedir. Bu açıdan gelecekte 
ortaokul öğrencilerine matematik öğretecek öğretmen adayların kullanılacak yöntemler hakkındaki görüşleri ülkemizin eğitimi açısından başarılması gereken düzey için önemli ipuçları sağlayacağı düşünülmektedir. Bu açıdan, öğrenenlerin yararına olan vurgularından ve varsayılan motivasyon güçlerinden dolayı bağlam temelli problemlerin (Gravemeijer \& Doorman, 1999), dolayısıyla bağlam temelli öğrenmenin önemli yeri vardır. Bağlamsal matematik problemlerini çözme, 21. yüzyılda öğrencilerin ihtiyaç duyacağı becerileri kazanmalarında önemli bir role sahiptir (Lutfianto ve diğ., 2013).

Üniversite öğrencilerinin bağlam temelli öğrenmeye nasıl yaklaştığını araştırmak için daha fazla çalışmaya ihtiyaç vardır (Parchmann ve diğ., 2015). Problem çözme sürecini etkileyen faktörlere yönelik yapılan sinıflandırmalarda, duyuşsal faktörlerin önemli bir yeri bulunmaktadır (Taşkın, Aydın, Akşan \& Güven, 2012). Mevcut çalışmamızda da bağlam temelli problem çözme sürecini etkileyen faktörlerden biri öğretmen adaylarının tutumlarını belirlemektir. Bu amaçla öğretmen adaylarına iki açık uçlu soru yöneltilmiş ve bunun sonucunda onların bağlam temelli öğrenmeye ilişkin tutumlarının ne olduğu tespit edilmeye çalışılmıştır.

\section{Yöntem}

$\mathrm{Bu}$ araştırma nitel olarak yürütülen bir çalışmadır. Çalışmada matematik öğretmen adaylarının bağlam temelli öğrenme ve bağlam temelli problemler hakkındaki görüşlerinin derinlemesine incelenmesi amacıyla olgubilim (fenomenolojik) modeli tercih edilmiştir. Fenomenolojik çalışma birkaç kişinin bir fenomen veya kavramla ilgili yaşanmış deneyimlerinin ortak anlamını tanımlar (Creswell, 2003). Fenomenolojinin temel amacı bir fenomenle ilgili bireysel deneyimleri evrensel nitelikteki bir açıklamaya indirgemektir (Creswell, 2003). Yukarıda tanımlanan amacı gerçekleştirme kapsamında bağlam temelli öğrenme ve bağlamsal problem çözme konusunda yeterli bir bilgi birikimi olmadığı kabul edilerek, öğretmen adaylarının görüşlerinin incelenmesinin önem teşkil ettiği düşünülmüştür. İstenilen verilerin elde edilebilmesi için gerekli olan koşulun öğretmen adaylarının bağlam temelli öğrenme sürecine katılmasıdır. Bu amaçla 6 haftalık bir süreçte öğretmen adayları bağlam temelli öğrenme, bağlamsal problem kurma ve çözme sürecine dahil edilmişlerdir. 
Araştırma Grubu

Araştırmanın çalışma grubu 2018-2019 öğretim yılı bahar döneminde, Güneydoğu Anadolu Bölgesinde bulunan bir devlet üniversitesinin, eğitim fakültesi matematik ve fen bilimleri eğitimi bölümü, matematik eğitimi anabilim dalında okuyan “Öğretim Teknolojileri ve Materyal Geliştirme Dersini" alan öğretmen adayları arasından seçilmiştir. Araştırma için seçilen 12 (8 bayan, 4 erkek) öğretmen adayı, aynı zamanda gönüllü olarak Bilimsel Araştırma Projeleri kapsamında kabul edilen bağlam temelli öğrenme ve bağlamsal problemler ile ilgili projeye katılım gösteren ve bu proje çerçevesinde bağlam temelli materyal tasarımına katılan öğretmen adaylarıdır. Bu yönüyle örneklem amaçlı örnekleme uygun düşmektedir. Amaçlı örnekleme için Punch (2005), belirli bir amaçla veya odaklanılan konuyla ilgili olarak örneklemin önceden düşünülüp belirlenmesi olduğunu söylemektedir. $\mathrm{Bu}$ araştırma için de araştırma sürecine doğrudan katılımda bulunmuş öğretmen adaylarının konuyla ilgili en iyi veri kaynakları olduğu göz önüne alındığında amaçlı örneklem seçimi savunulabilir.

\section{Veri Toplama Araçları ve Süreci}

Veri toplama süreci, öncelikle öğretmen adaylarının “Öğretim Teknolojileri ve Materyal Geliştirme” dersi süresince informal olarak gözlemlenmesi ve bu gözlemlerden elde edilen birtakım sonuçlara odaklı olarak başlatılmıştır. Öğretmen adaylarının süreç içindeki ilgileri ve anlamakta zorluk yaşadıkları durumlar tespit edilmeye çalışılmıştır. Öğretmen adayları bu süreç içinde kendi yaşadıkları zorlukları aşmak için bireysel görüşlerini sınıf arkadaşlarıyla paylaşarak çözüm üretmeye çalışmışlardır. Öğretmen adaylarının bu tür çabaları izlenmiştir. Bunun yanında öğretmen adaylarının bu araştırmayı yürüten akademisyenlere yönlendirdikleri sorular dikkate alınarak altı hafta boyunca gözlemlenmiş ve bu gözlemler değerlendirilmiştir.

Yapılan gözlemlerden elde edilen sonuçlara ilişkin daha net verilere ulaşmak için elde edilen gözlem verileri yarı yapılandırılmış görüşme formuna dönüştürülmüştür. Ayrıca konuyla ilgili literatür incelenmiş ve 20 sorudan oluşan yarı yapılandırılmış görüşme formu geliştirilmiştir. $\mathrm{Bu}$ form bağlam temelli öğrenme alanında uzman iki öğretim üyesine incelettirilerek formun tutarlılığı hakkında görüşleri alınmıştır. Uzmanlardan gelen dönütler doğrultusunda formdaki bazı soruların tekrar niteliğinde cevaplar üretebileceği algısı ile altı soru formdan çıkarılmıştır. Daha sonra soruların anlaşılırlığını test etmek açısından iki 
dördüncü sınıf iki üçüncü sınıf öğretmen adayına okutularak muğlak veya anlaşılmayan ifadelerin olup olmadı̆̆ı anlaşılmaya çalışılmıştır. Elde edilen sonuçlara göre formun anlaşılır olduğu kanaatine ulaşılmıştır. Bu süreçlerin sonucunda geliştirilen nihai form öğretmen adaylarına uygulanmıştır. Elde edilen veriler göz önüne alındığında bazı sorulara $(8,9,10)$ verilen cevapların önceki sorulara $(1,2,3,4,5,6,7)$ verilen cevaplara benzer veya tekrar niteliğinde olduğu görülmüştür. $\mathrm{Bu}$ nedenle ilgili soruların veri analizinde değerlendirilmemesine karar verilmiştir. Formda yer alan bazı sorular şunlardır: Sizce bağlam temelli öğrenme nedir? Nasıl tanımlarsınız? Bağlam temelli öğrenmeye dayalı yürütülen matematik derslerinin sizlere neler kazandırdığını düşünüyorsunuz? Matematik dersindeki kavramların, bağlamların, günlük yaşamdan örneklerle desteklenmiş bağlam temelli problemlerle birlikte anlatılması hakkındaki görüşleriniz nelerdir?

\section{Verilerin Analizi}

$\mathrm{Bu}$ araştırmada veri analizinde içerik analizi kullanılmıştır. İçerik analizinde temel amaç, toplanan verileri açıklayabilecek kavramlara ve ilişkilere ulaşmaktır (Çepni, 2014). İçerik analizinde temelde yapılan işlem, birbirine benzeyen verileri belirli kavramlar ve temalar çerçevesinde bir araya getirmek ve bunları okuyucunun anlayabileceği bir biçimde düzenleyerek yorumlamaktır (Çepni, 2014). Bu araştırmada da kullanılma gerekçesi yukarıda belirtilen amaçları içermektedir. Literatürde içerik analizi ile ilgili farklı yorumlar mevcut olsa da bazı konu uzmanlarına göre elde edilen benzer cevapların sayısallaştırılmasına gerek olmadığıdır (Gibbs, 2007). Bu yönüyle ele alınan veriler araştırmacılar tarafından kontrol-kodlamasına (Miles \& Huberman, 2015) tabi tutularak kodlanmış ardından bu kodlamaya uygun düşen kategoriler derlenmiştir. Kategori değerlendirmesi sonucunda kategoriler arası ilişkiler incelenmiş ve bu araştırmanın sonuçlarını gösteren bir şemaya ulaşılmıştır.

\section{İşlem}

Öğretmen adaylarına başlangıç aşamasında farklı soru tipleri adı altında ancak herhangi bir isimlendirme yapılmadan çeşitli problemler sorulmuştur. Bu problemlerin bazıları bağlamsal nitelikte olup özel olarak seçilmiştir. İlerleyen süreçte bu tür problemlerin sayısı artırılmış ve diğer problemlerle arasındaki fark öğretmen adaylarına sorulmuştur. Bu süreçte öğretmen adaylarından beklenen davranış, bağlamda meydana gelen değişime bağlı olarak sorunun niteliğindeki değişimin farkına varmaları şeklindedir. Altı haftalık çalışma 
sürecinin başında öğretmen adaylarına bağlamsal öğrenmeye yönelik bir takım teorik bilgiler aktarılmıştır. Öğretmen adaylarıyla yapılan karşılıklı sözlü değerlendirmede verilmek istenen bu teorik kavramların istenen düzeyde oluşmadığı görülmüştür. Bu yüzden başka bir yöntem denenmeye karar verilerek buluş yoluyla öğretim stratejisi benimsenmiştir. $\mathrm{Bu}$ öğretim stratejisiyle bağlam kavramının daha sağlıklı oluşturulabileceğine karar verilmiştir. Böylece öğretmen adaylarına bağlamın neden önem taşıdığı ve günlük yaşamda karşılaşılan durumların çoğunlukla bağlamsal olduğu anlatılmıştır. Öğretmen adaylarının başlangıç aşamasında bu problemlere yönelik ilgisi yüksek olmasına rağmen problemleri çözme başarıları zayıf kalmıştır. Ancak ilerleyen süreçte alışma devresini geride bırakan öğretmen adaylarının bu tip problem durumlarına adaptasyon sağladıkları görülmüştür. Yapılan bu uygulamalar 6 haftalık süreci kapsamıştır. Bu süreç sonunda öğretmen adaylarının bağlamsal öğrenmeye bakış açılarını değerlendirme olanağı bulunmuştur.

\section{Bulgular}

Bu nitel araştırmada öğretmen adaylarının görüşme formunda kendilerine yöneltilen sorulara verdikleri cevaplardan elde edilen bulgular, araştırmanın amacına uygun bir şekilde oluşturulan örnek kodlar ve kategoriler altında tablolarda ele alınmıştır.

Öğretmen adaylarının isimlerinin verilmesi etik açıdan doğru kabul edilmediğinden görüşleri aktarılırken her öğretmen adayının görüşü için Ö1, Ö2 ... şeklinde kısaltmalar kullanılmıştır. Katılımcıların verdikleri ifadelerin tamamı tablolardaki veri örneklerinde kullanılmamış bunun yerine veri azaltma yöntemi ile birinci aşama kodlamaların yazılması amacıyla tercih edilmiştir. Bununla birlikte tablolarda ifade edilen bulgularla beraber, öğretmen adaylarının verdiği cevaplardan bir örnek doğrudan alıntı olarak verilmiştir. Bütün nitel bulgularda olduğu gibi burada da araştırmanın pragmatik yönü göz önüne alınarak bulgular sınıflandırılmıştır.

Tablo 1. Öğretmen adaylarının "sizce bağlam temelli öğrenme" nedir? Nasıl tanımlarsınız? Sorularına verdikleri cevapların analizi

\begin{tabular}{|c|c|}
\hline Örnek kodlar & Kategoriler \\
\hline $\begin{array}{l}\text { Ö1: Çevre ile etkileşim, kalıcı öğrenme, kavram } \\
\text { bağlantısı }\end{array}$ & \multirow{5}{*}{$\begin{array}{l}\text { Dönüştürme (gerçek dünyadan elde edilen } \\
\text { verilen zihinsel olarak ifadesi) }\end{array}$} \\
\hline Ö2: Başka şeylerle ilişkilendirme & \\
\hline Ö3: Günlük yaşamla ilişkilendirme & \\
\hline Ö4: Matematiği günlük yaşamla uyumlu görmesi & \\
\hline $\begin{array}{l}\text { Ö9: Günlük yaşam problemlerine matematiksel } \\
\text { yaklaşımı sağlar }\end{array}$ & \\
\hline
\end{tabular}


Tablo 1'deki görülen kodlama verileri, öğretmen adaylarının bir takım günlük yaşam etkileşimini matematikselleştirdiğini ifade etmektedir. Öğretmen adaylarının ağırlıklı olarak ilişkilendirme olgusuna eğildiği görülebilir. İlişkilendirmenin esas olarak öğretmen adaylarının zihinlerindeki bilgi ile nesnel dünya arasındaki örtüşme olduğu görülmektedir. Bu durum da esas olarak nesnel dünya materyallerinin zihinsel, matematiksel dönüşümünü ifade ettiği görülmektedir. Buna somut bir örnek, öğretmen adaylarının verdikleri cevaplardan seçilmiş ve aşağıda verilmiştir.

1. Sizce "Bağlam Temelli Öğrenme" nedir? Nasıl tanımlarsınız?

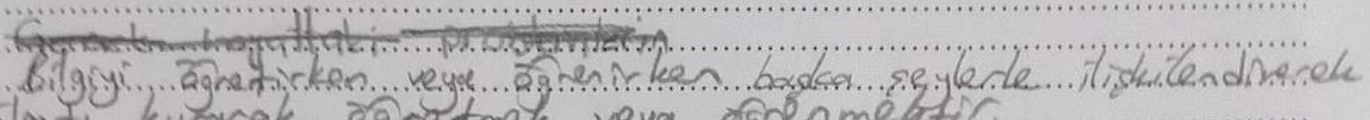

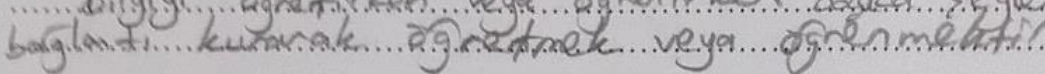

Tablo 2. Öğretmen adaylarının "bağlam temelli öğrenmeye dayalı yürütülen matematik derslerinin sizlere neler kazandırdığını düşünüyorsunuz? Maddeler halinde yazınız" sorusuna verdikleri cevapların analizi.

\begin{tabular}{|c|c|}
\hline Örnek kodlar & Kategoriler \\
\hline Ö1: Kavramları soyutlamasını sağlamak & \multirow{10}{*}{$\begin{array}{l}\text { Somutlaştırma } \\
\text { (Kalıcı, gerçek öğrenme ve günlük yaşam ile } \\
\text { ilişkilendirme) }\end{array}$} \\
\hline Ö2, Ö3, Ö4, Ö5: Kalıcı öğrenme, gerçek öğrenme, & \\
\hline kolay öğrenme & \\
\hline $\begin{array}{l}\text { Ö6: Kalıcı öğrenme, öğrenme isteği, motivasyon, } \\
\text { öğrencilerin bilgileri havatta uvgulaması }\end{array}$ & \\
\hline Ö10: Gerçek yaşantı yoluyla öğrenmenin daha & \\
\hline kalıcı olması, kavramların tam olarak öğrenilmesi & \\
\hline Ö8: Muhakeme becerisi kazandırır & \\
\hline Ö9: Akıl yürütme ve gerçek yaşamla bağdaştırma & \\
\hline Ö10: Matematik dersine olan ilgi ve tutum artar, & \\
\hline kalıcı öğrenme, akıl yürütme & \\
\hline
\end{tabular}

Tablo 2'deki veriler dikkate alındığında öğretmen adaylarının matematik öğrenmede ve matematik kavramlarını anlamada somutlaştırmaya önem verdikleri söylenebilir. Diğer bir deyişle öğretmen adayları somutlaştırmanın öğrenme üzerinde olumlu etkilere sahip olduğunu ifade etmektedirler. Örneğin kalıcı, gerçek (nesnel dünya ile örtüşen), kolay edinilmeye yol açan bilgi şeklinde ifade edildiği görülmektedir. Tüm bu basamakların somutlaştırma kategorisi altında toplanabileceği görülmektedir. Öğretmen adaylarının verdikleri cevaplardan biri örnek olarak aşağıda sunulmuştur. 
2. Başlam temelli oğrenmeye dayah yüratälen ma

matematik derslerinin sizlere neler kazandırdığın

usşùnuyorsunuz? Maddeler halinde sıralayınız

Matenadbel........ problente.

prostanterte.

gormes .....thite.

bacgdentrimat.

mastenats

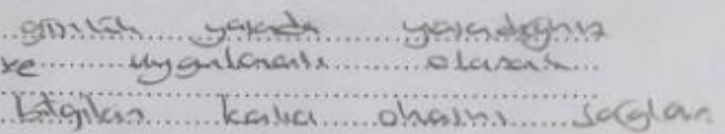

Tablo 3. Öğretmen adaylarının "Bağlam temelli problem" ve "Bağlam temelli olmayan problem" sizin için ne anlam ifade ediyor? Bu problemlerin çözüm stratejileri konusunda ne düşünüyorsunuz?" sorusuna verdikleri cevapların analizi.

\section{Örnek kodlar}

Kategoriler

Ö1: Problemi gerçek manada zihinde

tasarlamak ve mantıksal bir düşünme yolu

üretmek

Ö2, Ö3: İlişkilendirme ve ilişkilendirmeme

Ö4: Gerçek yaşamla ilişkili olup olmama

Ö5: Akıl yürütmeyi geliştirme

Ö6: Bağlamsal olmayan problemler düz anlatım ve ezber

Ö8: Somut örnekler

Bağlamsal: Somutlaştırma $\rightarrow$ kolay akıl yürütme Bağlamsal olmayan: Soyut kalma $\rightarrow$ işlemsel bilgi

Ö9: Bağlamsal olmayan problemler sadece

işlem becerilerini geliştirir

Ö10: Yorumlama

Ö11: Bağlam, sınıf, çevre

Ö12: Bağlamsal olmayan problemlerde

anlamlandırma yoktur

Tablo 3 incelendiğinde, öğretmen adaylarının bağlamsal öğrenme için somutlaştırmanın yapılabilmesinin kolay akıl yürütmeye yol açtığını ifade ettiği görülmektedir. Öğretmen adayları bağlamsal olmayan öğrenme için soyut ve işlemsel bilgi ifadesini kullanmaktadırlar. Ayrıca bağlamsal olmayan problem durumları için matematiksel ifadeleri anlamlandırma zorluğu yaşadıklarını, soyut problem çözmenin işlemsel bilgiyi geliştirdiğini ifade ettiklerini görmek de mümkündür. Buna göre öğretmen adaylarının bağlamsal öğrenme yolu ile somutlaştırmadan dolayı daha kolay akıl yürütme yapabileceklerini ifade ettiklerini belirlemek önem taşımaktadır. Bu soruya yönelik bulguların analizi sonucu iki kategori ile ifade edilmiş olup bunlar bağlamsal ve bağlamsal olmayan şeklinde adlandırılmıştır. Öğretmen adaylarının üçüncü soruya verdikleri cevaplara doğrudan bir alıntı için aşağıda bir örnek gösterilmiştir.

3. "Bağlam temelli problem" ve "bağlam temelli olmayan problem" sizin için ne anlam ifade ediyor? Bu problemlerin çözüm stratejileri konusunda ne düșünüyorsunuz?

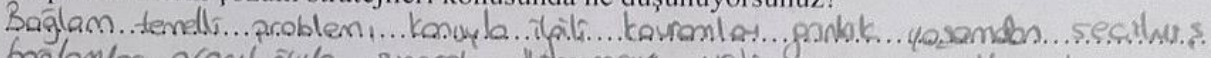

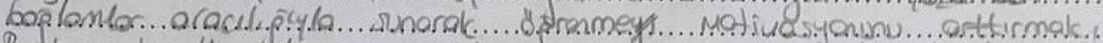

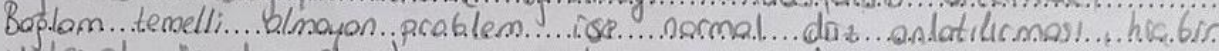
motema!... drnak ..... olmaton ..... sun mok. ...

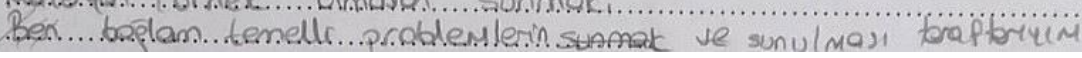


Tablo 4. Öğretmen adaylarının “Bağlam temelli problemleri çözerken, problem çözme aşamalarından yararlanma konusunda ne düşünüyorsunuz?” sorusuna verdikleri cevapların analizi.

\section{Örnek kodlar Kategoriler}

Ö1: Kolay problem çözme, basitten zora

kavrama (aşamalı öğrenme)

Ö2: Daha kolay

Ö3: Probleme uygun strateji belirlemek

Somut materyal $\rightarrow$ kolay düşünme

Ö4: Kolay çözme, anlayarak öğrenme

Ö5: Daha kolay anlama

Ö6: Daha kolay anlama, somut aktarım

Tablo 4'ten öğretmen adaylarının problem çözme sürecinde somut materyal üzerinde düşünmenin kolay olduğunu ve bunun daha kolay düşünmeye yol açtığını ifade ettiklerini görmek mümkündür. Somut olaylar üzerinde düşünürken daha kolay strateji geliştirme ve anlam oluşturmanın daha kolay olduğu bilinmektedir. Öğretmen adaylarının bu yönlü belirlemeleri somut materyal ile kolay düşünme arasında bir ilişki olarak ifade edilmiştir. Katılımcıların dördüncü soruya verdikleri cevaplardan bir örnek aşağıda gösterilmiştir.

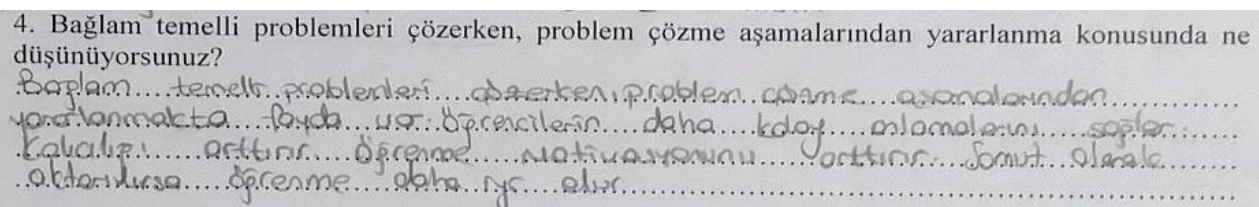

Tablo 5. Öğretmen adaylarının "Bağlam temelli olmayan problemleri çözerken, problem çözme aşamalarından yararlanma konusunda ne düşünüyorsunuz" sorusuna verdikleri cevapların analizi.

Örnek kodlar

Kategoriler

Ö1: Soyut matematik, bağdaştırma zorluğu

Ö2: Kalıcı olmayan öğrenme

Ö4: Düz anlatımla aktarım

Ö6: Anlaşılma zorluğu, anlamlandırma zorluğu

Ö7: Ezber

Ezber ve sınırlı öğrenme, prosedür uygulama

Ö8: Ezber, prosedür uygulama

Ö9: Sınırlı öğrenme

Ö13: İşlemsel

Tablo 5'de öğretmen adaylarının beşinci soruya verdikleri cevapların analizine ait bulgular görülmektedir. Bağdaştırma zorluğu, kalıcı olmayan öğrenme, düz anlatım gibi ifadeler sınırlı bir öğrenme oluşumuna yol açan, bağlamsal olmayan durum hakkındaki görüşleri ifade etmektedir. Elde edilen veriler kodlandığında ortaya çıkan durum ezber ve sınırlı öğrenme, prosedür uygulama şeklinde genel olarak anlamlandırılabilir. Öğretmen adaylarının özellikle vurguladığı önemli kavramlardan biri anlaşılma zorluğu ve kalıcı 
olmayan öğrenme bu araştırma açısından önem taşımaktadır. Öğretmen adaylarının verdikleri cevaplardan bir örnek aşağıda sunulmuştur.

5. Bağlam temelli olmayan problemleri çözerken, problem çözme aşamalarından yararlanma konusunda ne düşünüyorsunuz?

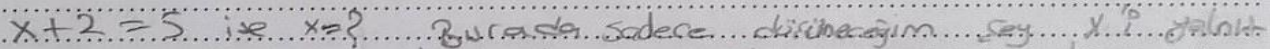

Tablo 6. Öğretmen adaylarının "Matematik dersindeki kavramların, bağlamların, günlük yaşamdan örneklerle desteklenmiş bağlam temelli problemlerle birlikte anlatılması hakkındaki görüşleriniz nelerdir? Açıklayınız" sorusuna verdikleri cevapların analizi.

\section{Örnek kodlar}

Kategoriler

Ö1: Daha anlamlı öğrenme

Ö2, Ö4: Kalıcı kavram öğrenme, daha iyi ve

kalıcı öğrenme

Ö5: Matematiği sevdirme, günlük yaşamda akıl

yürütme

Ö6: Problem çözmeyi kolaylaştırma

Ö7: Kalıcı bilgi, zevkli öğrenme, üretkenliği

artırma

Ö8: Somut matematik

Ö9: Dikkat çekici, kalıcı, matematiğe olan ilgi

artış1

Ö10: Kalıc1, çevre, anlama

Ö11: Etkin kavramlar, günlük yaşamla

ilişkilendirme

Ö12: Problemlerin daha iyi anlamlandırılması

Ö13: Günlük yaşam problemlerinin daha kolay

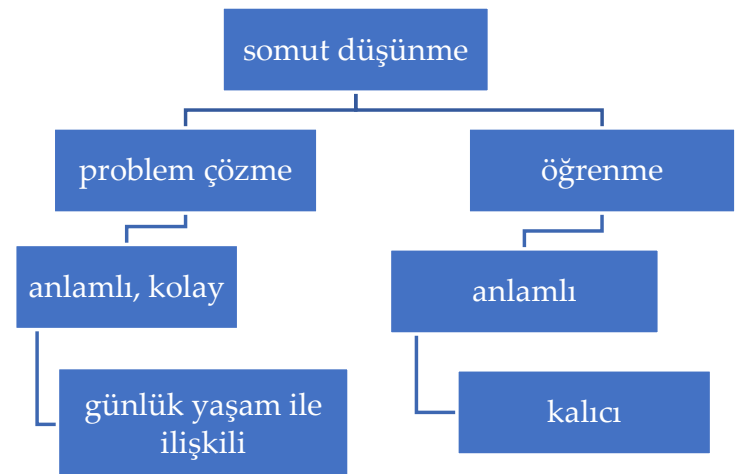

Şekil 1. Somut düşünmenin yol açtığ1 sonuçlar.

çözülmesi

Tablo 6’ya göre öğretmen adaylarının altıncı soruya verdikleri cevapların analizi sonucu elde edilen bulgular görülmektedir. Bu bulgulardan daha kolay muhakemenin somut düşünmeye bağlı olduğu ve somut düşünmeye dayalı yaklaşımın anlamlı ve kolay öğrenmeye yol açtığ1 ve bu durumun günlük yaşam ile ilişkili olduğundan soyut bir anlam üretmekten ziyade ilişkili bir öğrenme ortaya çıkardı̆̆ı görülmektedir. Diğer taraftan öğretmen adaylarının kalıcı öğrenme açısından da bakış açıları benzer şekildedir. Buna göre günlük yaşamda gözlemleyerek öğrenilen kavramların hatırlanması daha kolay olmaktadır. $\mathrm{Bu}$ durum ise farklı bağlantıların kurulmasını kolaylaştırmaktadır. Öğretmen adaylarının verdikleri cevaplardan bir örnek alıntı aşağıda verilmiştir. 
6. Matematik dersindeki kavramların, bağlamların, günlak yaşamdan öneklerle desteklenmiş bağlam temelli problemlerle birlikte anlatılması hakkındaki görüşleriniz nelerdir? Açıklayınız.

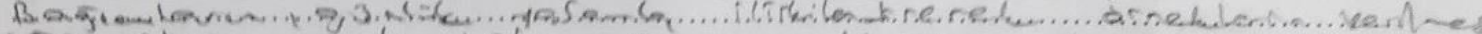

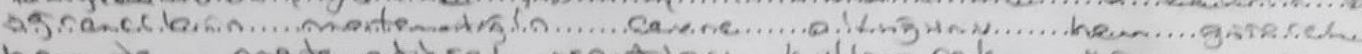

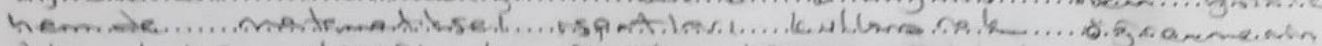

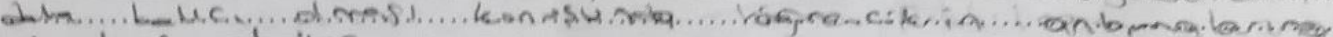
you dimes... alve yor.

Tablo 7. Öğretmen adaylarının "Bir matematikçi gözüyle, bağlam temelli materyal, sizin için ne anlam ifade ediyor?" sorusuna verdikleri cevapların analizi.

\begin{tabular}{|c|c|}
\hline Örnek kodlar & Kategoriler \\
\hline Ö1: Materyal, somutlaştırma & \\
\hline Ö2: Matematiği en kolay öğrenme yöntemi & \\
\hline Ö3: Günlük hayata uyarlama & somut \\
\hline Ö5: Günlük hayat ile uyumlu sunum & \\
\hline $\begin{array}{l}\text { Ö6: Kolay öğretim (anlamlandırma } \\
\text { zorluğuna çözüm) }\end{array}$ & soyut \\
\hline Ö8: İlgi çekici, kavram kazanımı, uygulama & \\
\hline Ö9: Sorunu matematik diliyle anlatmak & anlamlandirma \\
\hline Ö11: Öğrenciye uygun sunum, etkin & (uyarlama) dil \\
\hline öğrenme & \\
\hline Ö12: Gerçek yaşamdan bir problemi & düzeye uygun öğretme \\
\hline matematikselleştirmek & \\
\hline $\begin{array}{l}\text { Ö13: Matematiği daha kolay günlük yaşama } \\
\text { uyarlama }\end{array}$ & Şekil 2. Matematikselleştirme süreci. \\
\hline
\end{tabular}

Tablo 7'ye göre öğretmen adaylarının yedinci soruya verdikleri cevapların analizi sonucunda elde edilen bulgular kolay bir soyutlama (bilgi üretme) süreci için somutla başlayan bir süreci göstermektedir. Öğretmen adayları materyal kullanmanın bazı bilgileri daha kolay görmeye (anlamaya) yol açtığını çünkü materyal kullanmanın aynı zamanda ilgi çekici olduğunu görmek mümkündür. Öğretmen adaylarının ifadelerine bağlı olarak bu durumun düzeye uygun bir öğrenme için elverişli koşullar sağladığını ve aynı zamanda matematikselleştirme için de kolay bir zemin hazırladığını görmek mümkündür. Öğretmen adaylarının yedinci soruya verdikleri cevaplar için bir örnek aşağıda görülmektedir.

7. Bí matematikçi gözüyle "Bağlam Temelli Materyal " sizin için ne anlam ifade ediyor?

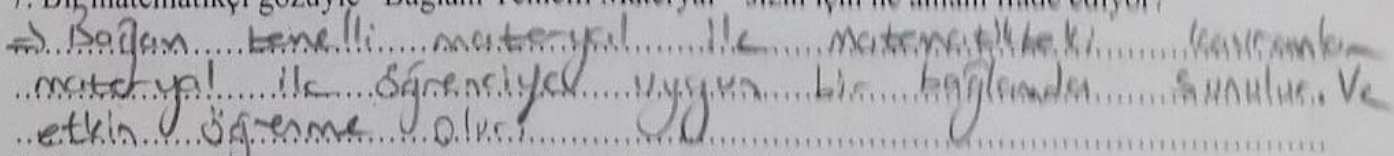

$\mathrm{Bu}$ araştırma kapsamında bazı (üç) öğretmen adaylarının soyut olarak öğrenilen matematiksel bilgilerin karşılığını nesnel dünyada aradıkları görülmüştür. Bu durum matematiği soyut birtakım uygulamalar yığını gibi algılayan öğrenen sınıflarında mevcuttur. Bağlamsal öğrenmede gerçek durum günlük yaşamdaki matematiği kavrama olması gerekir ancak burada bahsedilen üç öğretmen adayı dönüşümün ikinci aşaması olan soyuttan 
somuta kısmını düşünmekte oldukları görülmektedir. Bu durumun öğretmen adaylarının aldıkları eğitimden veya aldıkları eğitimi bu şekilde yorumlamış olmalarından kaynaklanmış olabilir. Şekil 3 bu durumdaki geçişleri göstermektedir.

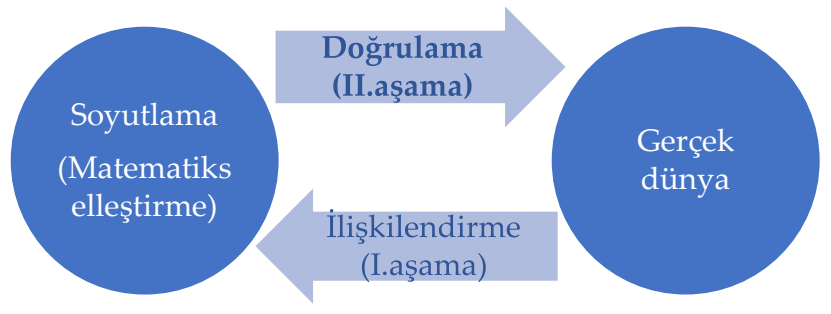

Şekil 3. Soyuttan somuta geçiş süreci

Tablo 8. Öğretmen adaylarının "Matematik derslerinizin geleneksel öğrenme yöntemleriyle mi, yoksa bağlam temelli öğrenme yöntemiyle mi işlenmesini istersiniz? Neden?" sorusuna verdikleri cevapların analizi

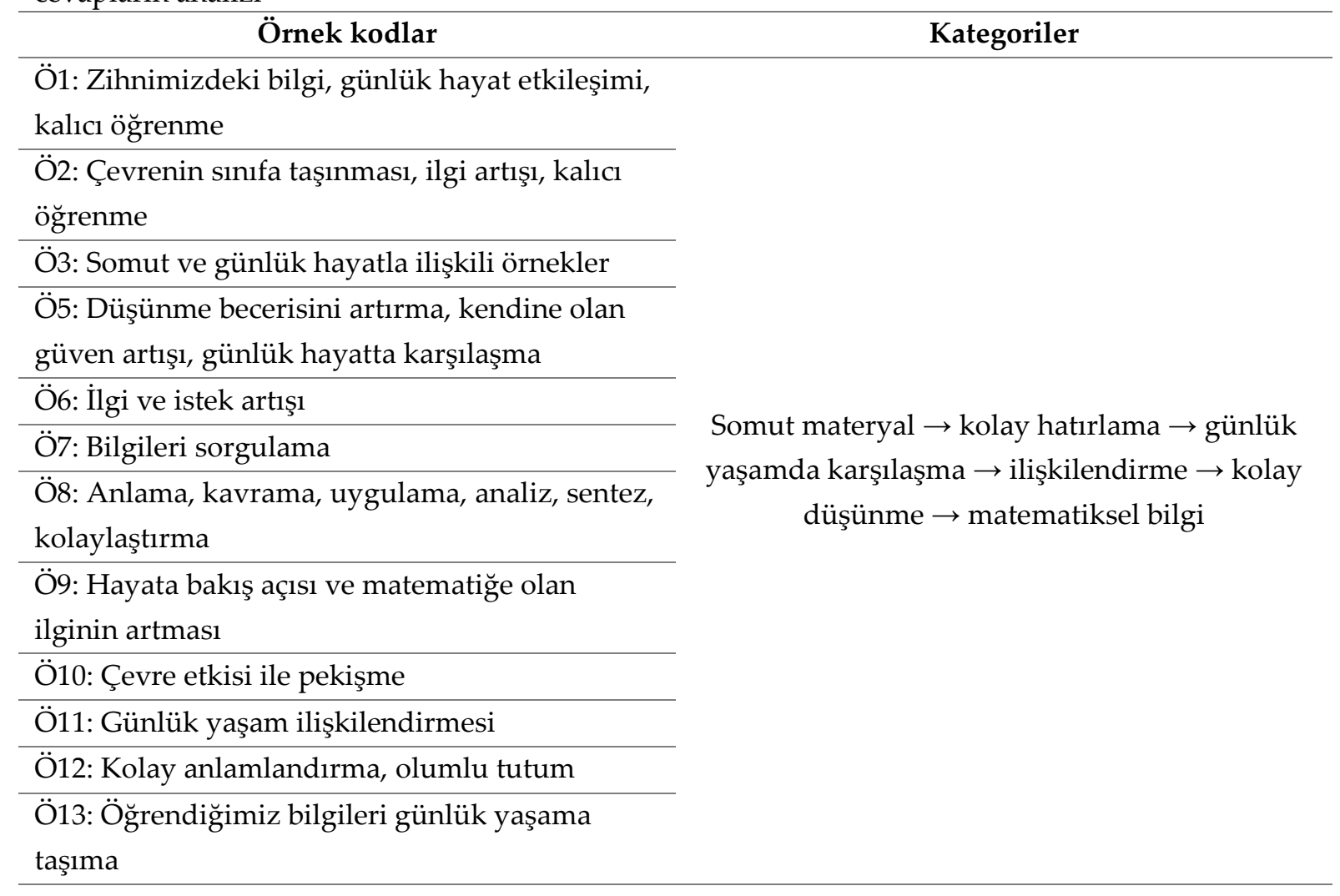

Tablo 8'de öğretmen adaylarının on birinci soruya verdikleri cevapların analizi sonucu elde edilen bulgular somut materyalin yol açtı̆̆ı kolay öğrenme ve muhakeme basamaklarını göstermektedir. Bu noktada ortaya çıkan kodların önceki kategorilerle tutarlı olduğu söylenebilir. Özellikle somut materyalin kolay hatırlama günlük yaşamda karşılaşma bunun da ilişkilendirmeye yol açtığ1 ve bu ilişkilendirmenin kolay düşünme ve matematiksel bilgiyi üretmeye yol açtığı görülebilir. Öğretmen adaylarının bu soruya ilişkin cevapları için bir örnek aşağıda verilmiştir. 
11. Matematik derslerinizin geleneksel öğrenme yöntemleriyle mi, yoksa bağlam temelli öğrenme yöntemiyle mi işlenmesini istersiniz? Neden?

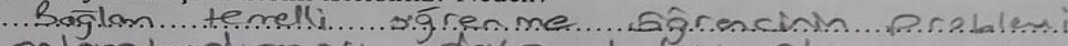

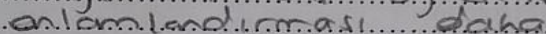

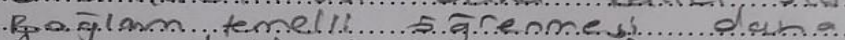

Bu...k on ud ciki fils i m .

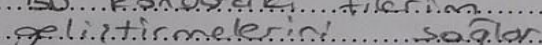

Tablo 9. Öğretmen adaylarının "Bağlam temelli öğrenmeye dayalı matematik derslerinde eksik gördüğünüz noktalar var mı? Varsa bunlar nelerdir?" sorusuna verdiklerin cevapların analizi

\section{Örnek kodlar}

Kategoriler

Ö1: İndirgeme zorluğu

Ö2: Doğru ilişkiler kurma problemi

Ö3: Materyal ve uzmanlık eksikliği

Ö4: Yok

Ö5: Bazı kavramların oluşturulma zorluğu (ör:

irrasyonel sayılar)

Ö8: Kaygilar

Ö9: Alan derslerinde gerçek hayat problemlerinin azlığı

Ö10: evrensel bir dilin öğretilme zorluğu

Ö11: günlük hayatla ilişkilendirmede bireysel zorluklar.

Tablo 9'dan öğretmen adaylarının bağlamsal öğrenmeye ilişkin birtakım zorluklar gördüklerini ve bunun daha çok indirgeme zorluğu olduğunu söylemek mümkündür. Örneğin irrasyonel sayıları gerçek yaşamla ilişkilendirmek bağlamsal öğrenme açısından bir zorluk olarak görülmektedir. Bu ve benzer durumlara yol açan nedenler arasında yeterli örneklerin azlığı ve uzmanlık gibi sorunlar olduğu ifade edilmektedir. Matematik öğrenen gurupların örneklere önem verdiği bilinmektedir. Öğretmen adaylarının ifadelerine bir örnek aşağıda görülmektedir.

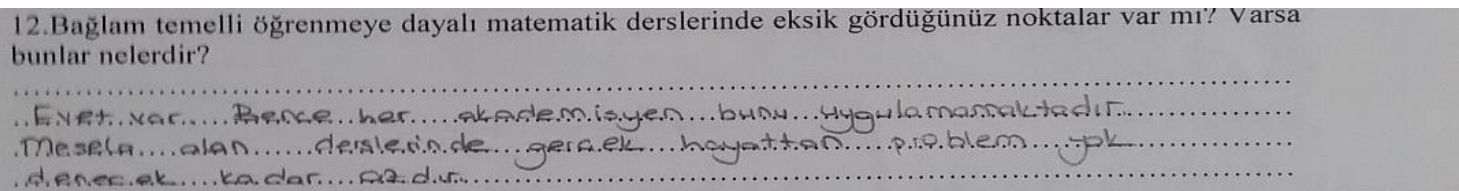

Tablo 10. Öğretmen adaylarının "Öğretmen olduğunuzda matematik derslerinizde bağlam temelli öğrenmeyi kullanmayı düşünür müsünüz? Niçin?" sorusuna verdikleri cevapların analizi

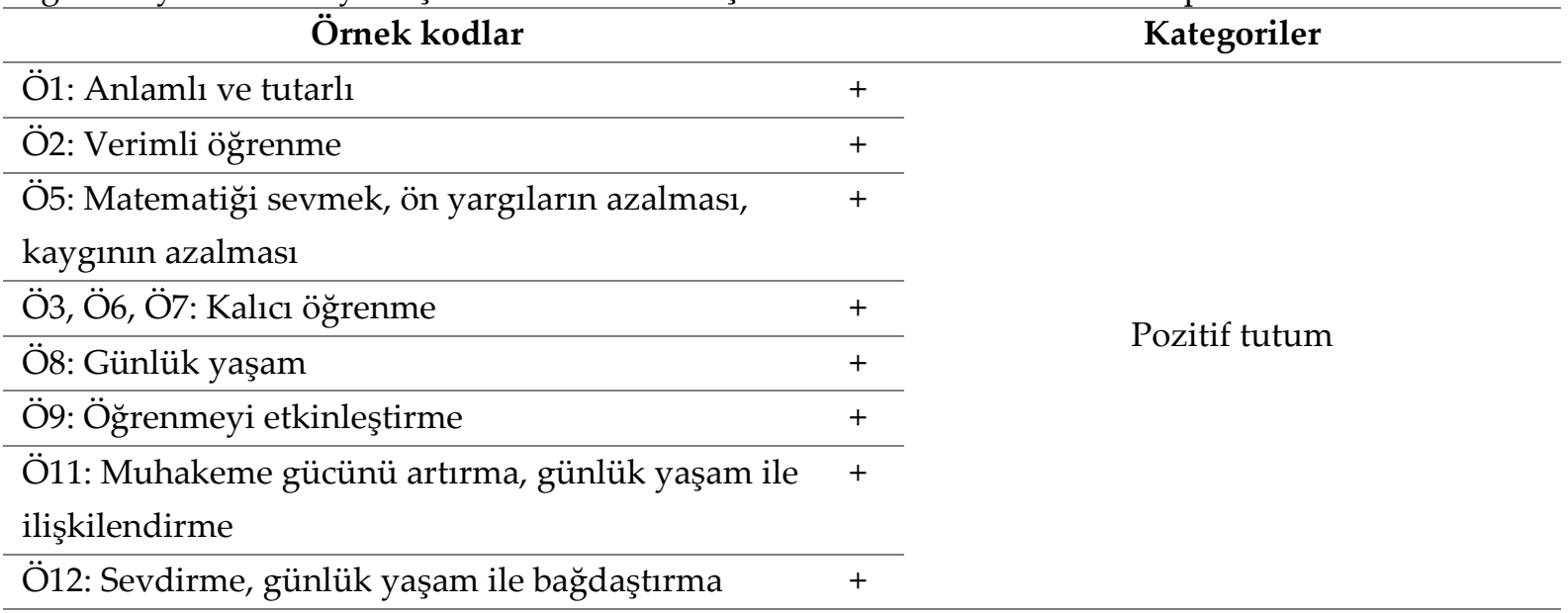


Tablo 10'dan elde edilen bilgiler, öğretmen adaylarının bağlam temelli öğrenmeye yönelik tutumları olarak ele alınabilir. Burada görüldüğü gibi öğretmen adaylarının mesleği icra döneminde bağlam temelli öğrenmeyi kullanmaya yönelik pozitif bir eğilim sergileyebilecekleri görülebilir. Özellikle sevdirme, günlük yaşam ile ilişkilendirme, kaygının azaltılması ve kalıcı öğrenmeye yol açtığı gibi ifadeler öğretmen adaylarının bağlam temelli öğrenmeyi neden kullanacaklarına yönelik pozitif bir yaklaşıma sahip olduklarını göstermektedir. Öğretmen adaylarının bu soruya cevap olarak ifade ettiği örneklerden biri aşağıda verilmiştir.

13.Ögrretmen olduğunuzda matematik derslerinizde bağlam temelli öğrenmeyi kullanmayı düşünür müsünüz? Niçin?

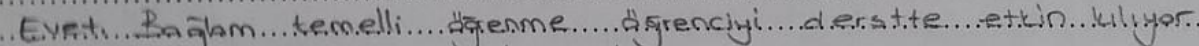

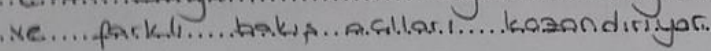

Tablo 11. Öğretmen adaylarının “Bağlam temelli öğrenme yöntemini bilmeden önce ve bildikten sonra matematiği sevme derecenizi 0-5 arasında derecelendirirseniz önce ve sonra vereceğiniz puan kaç olur?" sorusuna verdikleri puanlar.

\begin{tabular}{llllllllllllll}
\hline Önce & 4 & 3 & 3 & 2 & 4 & 4 & 5 & 3 & 4 & 2 & 3 & 2 & 4 \\
\hline Sonra & 5 & 4 & 3 & 4 & 4 & 5 & 5 & 5 & 5 & 4 & 4 & 5 & 5 \\
\hline
\end{tabular}

Tablo 11'e göre bağlamsal öğrenmenin öğretmen adaylarının matematiğe yönelik tutumlarını olumlu yönde etkilediği söylenebilir. Bu tür veriler her ne kadar objektif nitelikli veri olmasa da etik kurallar dikkate alındığında verilen cevapların doğru olduğu varsayımdan hareketle öğretmen adaylarının bağlam temelli öğrenme sonucu elde ettikleri olumlu tutumun matematiğe yönelik tutumu da olumlu etkilediği söylenebilir. Öğretmen adaylarının on dördüncü soruya verdikleri cevaplar için bir örnek aşağıda görülmektedir.

14. Baglam temelli ogrenme yöntemini bilmeden önce ve bildikten sonra matematiği sevme derecenizi

0-5 arasinda derecelendirirseniz ónce ve sonra vereceğiniz puan kạ̧ olur?

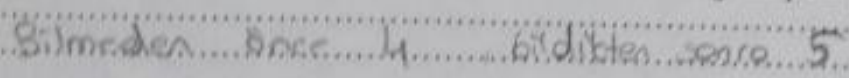

\section{Tartışma ve Sonuç}

Günümüz ulusları bilimsel ve teknolojik gelişim için hayati rol oynayan matematik eğitimini iyileştirmeye yönelik birçok kuramsal yaklaşımla yanıt aramaktadır. Genel olarak bu kuramların önemli bir kısmı gerçek dünya deneyimlerine matematiksel açıdan yaklaşılmasının önemli olduğunu belirtmektedir. Çünkü deneyim nesnel dünya ile birebir etkileşimi ve soyutlamayı içerir. Bağlam temelli öğrenmeye yönelik yapılan etkinlikler de bu türden deneyimleri barındırmaktadır. Bu nedenle mevcut çalışmada ortaya çıkan sonuçlar 
matematiğe yönelik bir takım tutum ve bilgiler gerektirdiği gibi aynı zamanda bunlarla paralel nesnel dünya deneyiminin psikolojik etkileşim kurallarını içermektedir. Örneğin çoğu öğrenen gurupların nesnel dünya ile ilişkili problemlerde ne yapacaklarını bilememesi bu türden görülen davranışlar arasındadır. Yu, Fan ve Lin'in (2014) ulaştığı, gerçek hayattaki bağlamlarda yeterince deneyim sahibi olmama sonucuna bağlamakla tutarlı görülmektedir. MEB'in (2009) program amaçlarını belirlemesine göre matematiği öğrenmek; temel kavram ve becerilerin kazanılmasının yanı sıra matematiksel düşünmeyi, genel problem çözme stratejilerini kavramayı ve gerçek yaşamda matematiğin önemli bir araç olduğunu takdir etmeyi içermektedir.

$\mathrm{Bu}$ çalışmada, öğretmen adaylarının yarı yapılandırılmış görüşme formunda yer alan bağlam temelli öğrenmeye ilişkin görüşlerinde ifade ettikleri cevaplardan yararlanılarak bir sonuç şeması oluşturulmuştur. Bu şema Şekil 4'te verilmiştir.

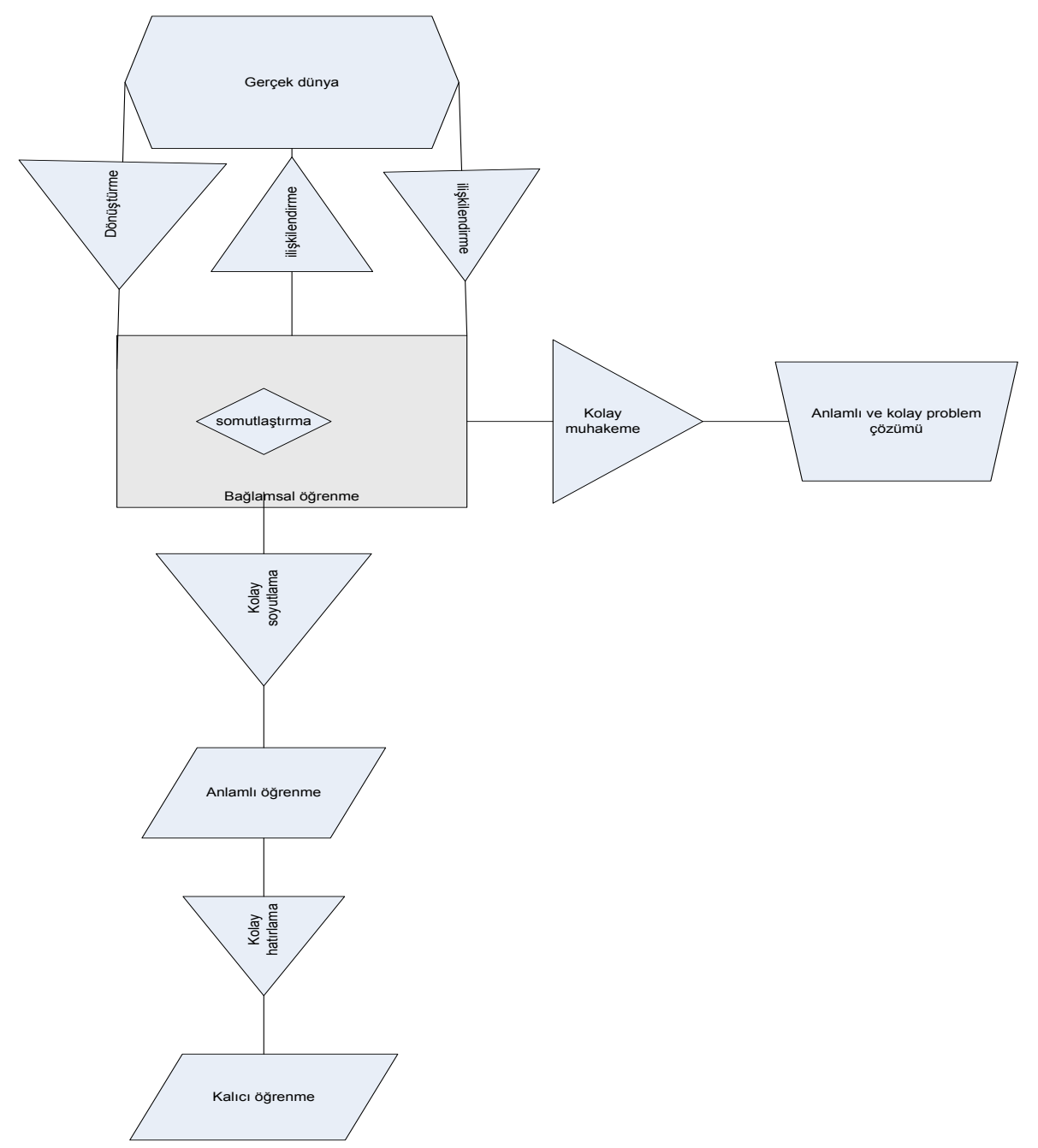

Şekil 4. Bağlam temelli öğrenme şeması 
Şekil 4'teki öğretmen adaylarının bağlam temelli öğrenmeye ilişkin ifade ettikleri cevaplardan elde ettikleri sonuç şeması incelendiğinde temel olgunun bağlamsal öğrenme düzleminde somutlaştırma olduğu görülmektedir. Somutlaştırmanın öncelikle kolay muhakemeye yol açtığı ve bunun da kolay ve anlamlı problem çözmeyi doğurduğu görülmektedir. Bağlam temelli öğrenmede somutlaştırmanın merkezde olmasının bir diğer olumlu sonucu nesnel durumların öncelikle kolay soyutlamaya yol açtığı bunun anlamlı öğrenmeyi doğurduğu ikinci aşamada meydana gelen durum ise nesnel olmasından dolayı kolay hatırlanması ve doğal olarak bunun kalıcı öğrenme üzerinde etkili olduğu görülmektedir. Bu çalışmada ortaya çıkan bir diğer bulgu ilişkilendirme boyutudur. Nesnel durum veya materyallerle çalışıldığında gerçek dünya ile matematiği ilişkilendirme için daha fazla bir çabaya gerek kalmadığıdır. İlişkilendirme öğretmen adaylarında iki boyutlu şekilde ortaya çıkmakta bunlardan biri nesnel dünyadan transfer edilen bilgi, diğeri matematiksel bilginin gerçek dünyadaki karşılıklarının bulunmasıdır. Bu süreçte ortaya çıkan soyutlama yani dönüştürme nesnel dünyadan alınan matematiksel bilgiyi var olan bilgi içinde rasyonalize etmektir.

Öğretmen adaylarının bağlam temelli öğrenmeye ilişkin kavramsal görüşlerinin alınması amacıyla "sizce bağlam temelli öğrenme" nedir? Nasıl tanımlarsınız? Sorusuna verdikleri cevaplardan elde edilen sonuçlar, nesnel dünya etkileşimi sonucu öğretmen adaylarının bilgiyi dönüştürdüğü ve bunu anlamlı hale getirdiğine ilişkindir. Esasen başlangıç düzeyinde matematiksel bilginin önemli bir kısmı bu türden dönüştürülmüş bilgiden oluşmaktadır. Bundan dolayı öğretmen adaylarının bu teşhisi önemli görülmektedir.

Genel olarak matematik öğrenen grupların en çok zorlandığı konuların başında bazı sayısal süreçlerin zihinde somutlaştırma aşaması gelmektedir. Öğretenlerin sıklıkla yaptıkları bir hata öğrenenlerin bu konuda yaşadıkları zorlukları göz ardı etmeleridir. Öğrenmede somut koşullardan yararlanan diğer kuramlar gibi bağlamsal öğrenme de öğrenenlere bu imkânı sağlamaktadır. Bu noktada öğretmen adaylarının “bağlam temelli öğrenmeye dayalı yürütülen matematik derslerinin sizlere neler kazandırdığını düşünüyorsunuz? Maddeler halinde yazınız" sorusuna verdikleri cevaplarda, öğretmen adayları somutlaştırmanın etkilerini ifade etmektedirler. Bu tür öğrenme kalıcı, gerçek ve günlük yaşam ile ilişkilendirilmiş olduğundan muhakeme edilme süreçlerini de daha kolay hale getirebileceği düşünülmektedir. 
Öğretmen adaylarının "bağlam temelli problem ve "bağlam temelli olmayan problem" sizin için ne anlam ifade ediyor? Bu problemlerin çözüm stratejileri konusunda ne düşünüyorsunuz?" sorusuna verdikleri cevapların analizi sonucunda sayısal süreçlerin zihinde somutlaştırma aşamasında ifade edilen durum yani somutlaştırma ve kolay akıl yürütme gerçekleşmediğinde geriye bir takım işlemsel bilginin uygulanması kalmaktadır. Genel olarak matematik eğitimindeki literatür (Baki, 2008) bu tür öğrenmenin öğrencilere yararlarının çok sınırlı olduğunu ifade etmektedir.

Öğretmen adaylarının “bağlam temelli problemleri çözerken, problem çözme aşamalarından yararlanma konusunda ne düşünüyorsunuz?" sorusuna verdikleri cevaplara göre, öğretmen adaylarının matematik eğitiminde düşünme problemine yönelik bir kolaylaştırma yaklaşımı taşıdığı görülmektedir. Bu sonuca benzer günlük yaşam etkinliği ve somut materyal kullanmayı gerektirdiğini ileri süren yaklaşımların kullanıldığı diğer araştırmalarda da rastlanmaktadır (Kılıç, Pekkan \& Karatoprak, 2013). Öğretmen adayları somut materyallerin öğrenenlerin düşünmesini kolaylaştırdığını belirtmektedirler. Bu duruma açıklayıcı bir örnek olması açısından, öğretmen adaylarının problem çözerken problem çözme aşamalarından yararlanma konusunda ne düşündüklerine ilişkin verdikleri cevaplar ele alınabilir. Bunun için bağlamsal öğrenmeye uymayan durumlarda ezber, sınırlı bir öğrenme ve sadece bir prosedürün uygulanması durumunu düşündüklerini, yani düşünmeye ve anlamlı öğrenmeye kapı aralamayan bir durumun ortaya çıktığını ifade etmişlerdir.

Öğretmen adaylarının "matematik dersindeki kavramların, bağlamların, günlük yaşamdan örneklerle desteklenmiş bağlam temelli problemlerle birlikte anlatılması hakkındaki görüşleriniz nelerdir? Açıklayınız" sorusuna verdikleri cevapların analizi sonucu somut düşünme sürecinin problem çözmeyi anlamlı ve kolay hale getirdiği ve günlük yaşam ile ilişkilendirilebilir bir düzeye taşıdığı görülmektedir. Esas olarak öğrenmenin anlamlı olduğu sürece kalıcı bir hale geldiği bilişsel psikoloji literatüründe sıklıkla ifade edilmektedir (Ormrod, 2013). Somut ortamda görülen ilişkilendirmenin daha kolay soyutlanabildiği, yani esnek bir bilgi oluşum sürecine girildiği bu yüzden anlam bileşenlerini oluşturmanın kolaylaştığı, somut olduğu için kolay hatırlandığı bu yüzden kalıcılığının arttığı söylenebilir.

Öğretmen adaylarının bağlam temelli öğrenmeye ilişkin görüşleri incelendiğinde materyal kullanımının öğretim açısından önemli görüldüğü, bunun matematik öğretim programı açısından (MEB, 2009) önemli bir olgu olduğu söylenebilir. Öğretmen adaylarının 
istenilen bir davranışı içselleştirmesi anlamına gelen bu durum, onların gelecekte ders tasarımında bu türden etkinliklere de eğilim göstereceği şeklinde yordanabilir. Öğretmen adayları bu duruma gerekçe olarak ifade ettikleri görüşler için "bir matematikçi gözüyle, bağlam temelli materyal, sizin için ne anlam ifade ediyor?" sorusuna verdikleri cevapların analizinde görülmektedir. Yapılan analiz sonucu ortaya çıkan kategorik ilişkilendirmede somut durumla başlayan ve ardından soyutlamanın yapıldığı anlamlı bir süreç oluştuğu bunun sonucunda düzeye uygun bir öğretime imkân sağladığı, bu durumun bir sonucu olarak da matematikselleştirmenin kolaylaşacağı sonucunu ürettiği görülmektedir.

$\mathrm{Bu}$ araştırmada dikkat çeken bir durum, üç öğretmen adayında görülen matematik anlayışına ilişkin olabilecek hatalı bir algıdır. Her ne kadar başka çalışmalarla incelenmesi gerekse bile burada şunu ifade etmenin yararlı olduğu kanaati taşınmaktadır. Matematik doğası gereği bir takım mantıksal kavram ve ilişkiler bütününü oluşturmaktadır. Bu mantıksal kavramların nesnel dünya ile birebir örtüşmesine gerek olmadığı matematik felsefesi açısından gündeme getirilmektedir (Baki, 2014). Ancak ilkokul ve orta öğretime yönelik öğretim programında bu türden ileri ve soyut bir yaklaşım öğrencilerin matematiğe yönelik pozitif algılarını olumsuz etkileyebilme potansiyeli taşımaktadır. Bazı öğretmen adaylarının bu yönlü, yani soyut matematiksel dünyadan gerçek yaşam üzerine bir eşleşme aradıkları görülmektedir. Genel olarak ilkokul ve ortaokul düzeyinde soyut bilgilerden ziyade somuttan-soyuta doğru bir bilgi oluşturma süreci yaşandığ 1 ve bu durumun yapılandırmacı yaklaşımın temel varsayımlarından biri olduğu bilinmektedir. Ancak burada öğretmen adaylarının bu ifadeleri ilkokul ve orta öğretim açısından yapılandırmacı yaklaşıma uygun olmayan bir anlayıştadır. Şekil 3 bu durumu ifade eden bir döngüyü göstermektedir.

Öğretmen adaylarının "matematik derslerinizin geleneksel öğrenme yöntemleriyle mi, yoksa bağlam temelli öğrenme yöntemiyle mi işlenmesini istersiniz? Neden?" sorusuna verdikleri cevapların analizinde önceki sorulara verdikleri cevaplarla tutarlı sonuçlar elde edilmiştir. Bu sonuç bu yönüyle veri tutarlılığı açısından ele alınabilir.

Her öğretim yönteminin bir takım eksik tarafları olması doğal kabul edilmektedir. Bu perspektifte bağlam temelli öğrenmenin de bazı eksikliklerinin olması beklenebilir. Bu eksikliklerin öğretmen adaylarına yansıma biçimleri bu açıdan önem taşımaktadır. Öğretmen adaylarının "bağlam temelli öğrenmeye dayalı matematik derslerinde eksik gördügünüz noktalar var mı? Varsa bunlar nelerdir?" sorusuna verdiklerin cevaplar bu 
eksikliklerin teşhisine yönelik öğretmen adaylarının gördükleri eksiklikleri göstermektedir. Yapılan analizler sonucu öğretmen adaylarının konu hakkında yeterli bir düzeyde olmadıkları, ancak aynı zamanda bir takım önemli görüşlere sahip oldukları söylenebilir. Etkinlik yaparak yürütülmekte olan derslerde en önemli olgulardan birinin zaman yönetimi olgusu olduğu bilinmektedir (Metin \& Özmen, 2009). Öğretmen adaylarının buna bağlı birtakım görüşlere sahip olmamaları öğretmenlik deneyimine sahip olmamalarından kaynaklanmış olabilir. Yukarıda belirtildiği gibi soyut matematiksel alandan gerçek dünya üzerine bir transferden söz edilmektedir. Ayrıca kaygı ve bazı kavramların oluşturulma zorluğu öğretmen adaylarını düşündürmektedir.

Yukarıda öğretmen adayları tarafından ifade edilen görüşlerin tutuma yönelik genel bir görünümü, öğretmen adaylarının “Öğretmen olduğunuzda matematik derslerinizde bağlam temelli öğrenmeyi kullanmayı düşünür müsünüz? Niçin?" sorusuna verdikleri cevapların analizi sonucunda elde edilen bulgular doğrultusunda ele alınabilir. Problem çözme sürecini etkileyen faktörlere yönelik yapılan sınıflandırmalarda, duyuşsal faktörlerin önemli bir yeri bulunmaktadır (Taşkın ve ark., 2012). Bu görüş dikkate alındığında öğretmen adaylarının genel olarak bağlam temelli öğrenmeye yönelik olumlu bir tutum sergilediği sonucuna ulaşılmıştır. Bu sonucun öğretmen adaylarının bağlam temelli öğrenmeye yönelik öğretmenlik mesleği sürecinde bu yöntemi kullanacaklarına yönelik pozitif bir beklenti oluşturmasına neden olduğu düşünülmektedir. Bilindiği üzere matematik öğretimine katk1 sağlayan her yöntem aynı zamanda matematiğe yönelik de olumlu bir tutumun gelişmesine yol açmaktadır. Çünkü matematik alanında elde edilen başarı öğrenenlerin derse ilgisini artırmakta ve Bloom (2012)'un ifade ettiği okulda öğrenme sürecinde duyuşsal bir etkiye yol açtığı bilinmektedir. Bu amaçla öğretmen adaylarının “bağlam temelli öğrenme yöntemini bilmeden önce ve bildikten sonra matematiği sevme derecenizi 0-5 arasında derecelendirirseniz önce ve sonra vereceğiniz puan kaç olur?" sorusuna verdikleri puanlar incelenmiştir. Buna göre yukarıda belirtildiği neden üzere bu tutumun aynı zamanda öğretmen adaylarının matematiğe yönelik tutumlarını da pozitif yönlü etkilediğini göstermektedir. Ancak bu verilerin objektifliği her araştırmada olduğu gibi tartışmaya açiktır.

$\mathrm{Bu}$ yaklaşımlarla birlikte öğrenen guruplarının günlük yaşam problemlerinin çözümünde beceri kazanmaları gerektiği söylenebilir. Bununla birlikte ilk etapta başarı oranlarının çok yüksek olması beklenmeyebilir. Tüm bu durumlar öğretmen adaylarının 
görüşlerini olumsuz olarak etkilemesi beklenen bir durumdur. Ancak yürütülen bu araştırmada öğretmen adaylarının karşılaşmış oldukları zorluklara rağmen görüşlerinin olumsuz yönde etkilenmediği görülmüştür.

Sonuç olarak bağlam temelli öğrenme öğretmen adaylarının perspektifinde öğretimde kullanılabilecek bir yöntem olarak işlevsel görüldüğü söylenebilir. Bu durum onların gelecekte bağlam temelli öğrenmeyi ortaokul öğrencilerinin matematik öğretiminde kullanacaklarına yönelik bir beklenti oluşturmaktadır. Dünyada ve ülkemizde hızlı bir şekilde günlük yaşamda problem çözmeye yönelen matematik eğitimi açısından öğretmen adaylarının bu yöntemlerden biri olan bağlam temelli öğrenmeye yönelik yaklaşımları gelecekte elde edilecek matematik başarısı açısından önem taşıdığı düşünülmektedir.

Bu çalışmada dikkat çeken faktörlerden biri öğretmen adaylarının bağlam temelli öğrenme ve bağlamsal problemler konusundaki deneyimsizliğidir. Benzer şekilde gelecekte yapılacak çalışmaların, aktif olarak görev yapmakta olan öğretmenlerle yapılmasının önemli sonuçlara ulaşmayı sağlayacağı düşünülmektedir. Ayrıca ortaokul öğrencilerinin günlük yaşamda sokak matematiği olarak adlandırılan matematiği hangi ölçülerde ve ne tür etkinliklerde kullandıkları önemli bir araştırma konusu olabilir. Bunun yanında öğretmen adayları, bağlam temelli öğrenmeye yönelik olumlu tutumlar sergilemelerine rağmen bu öğrenme yönteminde eksik kalan yönlerin belirlenmesi için üniversitede aldıkları problem çözme konusundaki derslerde bilgi, tutum ve algılarının nitel bir yaklaşımla derinlemesine değerlendirilmesinin yararlı olacağ

Bilgilendirme

Bu Araştırma Siirt Üniversitesi Bilimsel Araştırma Projeleri birimi tarafından 2018SIÜEĞT-054 proje numaralı "Bağlam temelli öğrenme yaklaşımının öğrencilerin matematik tutumuna, matematiksel düşünme düzeyine, kavramları öğrenme başarısına etkisi ve bu konudaki görüşleri" konusu ile ilgili olup, ilgili birimce desteklenmiştir.

\section{Kaynaklar}

Acar, B., \& Yaman, M. (2011). Bağlam temelli öğrenmenin öğrencilerin ilgi ve bilgi düzeylerine etkisi. Hacettepe Üniversitesi Eğitim Fakültesi Dergisi, 40(1), 1-10.

Altun, M. (2011). Ĕ̆itim fakülteleri ve lise matematik öğretmenleri için liselerde matematik öğretimi (17. Bask1). Bursa: Aktüel Alfa.

Aydın, Y., \& Yazgan, Y. (2018). Sosyal ve matematiksel sıradışı problem çözme becerileri arasındaki ilişki. Mehmet Akif Ersoy Üniversitesi Eğitim Fakültesi Dergisi, 48(4), 537554. Doi: 10.21764/maeuefd.414459

Baki, A. (2014). Matematik tarihi ve felsefesi. Ankara: Pegem Akademi. 
Baki, A. (2008). Kuramdan uygulamaya matematik eğitimi. Ankara: Harf Eğitim Yayıncılık.

Baki, A. (2018). Matematiği öğretme bilgisi. Ankara: Pegem Akademi Yayıncılık

Becher, J. P., \& Selter, C. (1996). Elementary school practice. In A. J. Bishop et al., (Eds.) International handbook of mathematics education. Dordrecht: Kluwer.

Bloom, B. S. (2012). Insan nitelikleri ve okulda öğrenme (Çeviren. D. A. Özçelik). Ankara: Pegem Akademi.

Choi, H. J., \& Johnson, S. D. (2005). The effect of context-based video instruction on learning and motivation in online courses. American Journal of Distance Education, 19(4), 215227.

Cobb, P., \& Yackel, E. (1998). A constructivist perspective on the culture of the mathematics classroom. In F. Seeger, J. Voigt, \& U. Waschescio (Eds.), The culture of the mathematics classroom. Cambrigde, UK: Cambridge University Press

Coştu, S. (2009). Matematik öğretiminde bağlamsal öğrenme ve öğretme yaklaşımına göre tasarlanan ögrenme ortamlarında öğretmen deneyimleri (Yayımlanmamış yüksek lisans tezi). Karadeniz Teknik Üniversitesi, Trabzon.

Creswell, J. W. (2003). Research design: Qualitative, quantitative, and mixed methods approaches. London, UK: Sage.

Çepni, S. (2014). Araştırma ve proje çalışmalarına giriş. Trabzon: Celepler Matbaacılık.

Değermenci, A. (2009). Bağlam temelli dokuzuncu sınıf dalgalar ünitesine yönelik materyal geliştirme, uygulama ve değerlendirme (Yayımlanmamış yüksek lisans tezi). Karadeniz Teknik Üniversitesi, Trabzon.

Demircioğlu, H. (2008). Sını öğretmeni adaylarına yönelik maddenin halleri konusu ile ilgili bağlam temelli materyal geliştirilmesi ve etkililiğinin araştırılması (Yayımlanmamış doktora tezi). Karadeniz Teknik Üniversitesi, Trabzon.

Gibbs, G. R. (2007). Analyzing qualitative data. California: Sage Publication.

Gök, B., \& Erdoğan, A. (2017). Sınıf ortamında rutin olmayan matematik problemi çözme: Didaktik durumlar teorisine dayalı bir uygulama örneği. Yüzüncü Yıl Üniversitesi Ĕ̆itim Fakültesi Dergisi, 14(1), 140-181.

Gravemeijer, K., \& Doorman, M.(1999). Context problems in realistic mathematics education: A calculus course as an example. Educational Studies in Mathematics, 39(1-3), 111-129.

Hadi, S. (2002). Effective teacher professional development for the implementation of realistic mathematics education in Indonesia (Doctoral dissertation). Enschede, the Netherlands: University of Twente.

Holman, J., \& Pilling, G. (2004). Thermodynamics in context: A case study of contextualized teaching for undergraduates. Journal of Chemical Education, 81(3), 373-375

Hoogland, K., Koning, J., Bakker, A., Pepin, B. E. U., \& Gravemeijer, K. (2018). Changing representation in contextual mathematical problems from descriptive to depictive: The effect on students' performance. Studies in Educational Evaluation, 58, 122-131. Doi: $10.1016 /$ j.stueduc.2018.06.004

Jazuli, A., Sulthon, P. S., \& Kuswandi, D. (2017). Improving conceptual understanding and problem-solving in mathematics through a contextual learning strategy. Global Journal of Engineering Education, 19(1), 49-52

Kılıç, H., Pekkan, Z. T., \& Karatoprak, R. (2013). Materyal kullanımının matematiksel düşünme becerisine etkisi. Eğitimde Kuram ve Uygulama, 9(4), 544-556

Kleden, M. A., \& Geradus, U. (2018). Enhancement of mathematical communication competency upon students of junior high school through contextual learning based on coastal culture. Education Quarterly Reviews, 1(1), 9-17. Doi: 10.31014/aior.1993.01.01.3 
Köse, E. Ö., \& Tosun, F. Ç. (2015). Biyolojide yaşam temelli öğrenmenin öğretmen adaylarının başarı ve tutumlarına etkisi. K. Ü. Kastamonu Eğitim Dergisi, 23(4), 14251436.

Lutfianto, M., Zulkardi, \& Hartono, Y. (2013). Unfinished student answer in PISA mathematics contextual problem. IndoMS-JME, 4(2), 188-193

Milli Eğitim Bakanlığ1 [MEB]. (2009). Illköğretim matematik dersi 6-8. sınıflar öğretim programı ve kılavuzu. Ankara: Talim Terbiye Kurulu.

Metin, M. \& Özmen, H. (2009). Sınıf öğretmeni adaylarının yapılandırmacı kuramın 5E modeline uygun etkinlikler tasarlarken ve uygularken karşılaştıkları sorunlar. Necatibey Eğitim Fakültesi Elektronik Fen ve Matematik Eğitimi Dergisi, 3(2), 94-123.

Miles, Matthew B., Huberman, A. M. (2015). Nitel veri analizi. (Çeviren: S. A. Akbaba-A. Ersoy). Ankara. Pegem Akademi.

Olkun, S., \& Uçar, Z. T. (2012). Ilköğretimde etkinlik temelli matematik öğretimi. Ankara: Eğiten Kitap

Ormrod, J. E. (2013). Öğrenme psikoloji. (Çeviren. M. Baloğlu). Ankara: Nobel Yayınevi

Özkan, G., \& Selçuk, G. S. (2017). Yaşam temelli öğrenme. B. Akçay (Ed.), fen bilimleri eğitimi alanındaki öğretme ve öğrenme yaklaşımları içinde (s. 255-264). Ankara: Pegem Akademi.

Özcan, Ö., \& Gerçek, C. (2015). What are the pre-service physics teachers' opinions about context-based approach in physics lessons? Procedia-Social and Behavioral Sciences, 197, 892-897. Doi: 10.1016/j.sbspro.2015.07.269

Parchmann, I., Broman, K., Busker, M., \& Rudnik, J. (2015). Context-Based teaching and learning on school and university level. In Javier Garc'ra-Mart'inez and Elena Serrano-Torregrosa (Etd). Chemistry Education (pp. 259-279). Weinheim: Wiley-VCH.

Parchmann, I., Grasel, C., Baer, A., Nentwig, P., Demuth, R., Ralle, B., et al. (2006). Chemie im Kontext-a symbiotic implementation of a context-based teaching and learning approach. International Journal of Science Education, 28(9), 1041-1062

Punch, K. (2005). Sosyal araştırmalara giriş (Çeviren Z. Akyüz, D. Bayrak ve H. B. Arslan) Ankara: Siyasal Kitabevi.

Rose, D. E. (2012). Context-based learning. In N. Seel (Ed.), Encyclopedia of the sciences of learning (pp. 799-802). New York: Springer US.

Saenz, C. (2009). The role of contextual, conceptual and procedural knowledge in activating mathematical competencies (PISA). Educational Studies in Mathematics, 71(2), 123-143.

Satriani, I., Emilia, E., \& Gunawan, M. H. (2012). Contextual teaching and learning approach to teaching writing. Indonesian Journal of Applied Linguistics, 2(1), 10-22.

Savard, A., \& Polotskaia, E. (2017). Who's wrong? Tasks fostering understanding of mathematical relationships in word problems in elementary students. ZDM Mathematics Education, 49(6), 823-833. Doi: 10.1007/s11858-017-0865-5

Shiu-Sing, T. (2005). Some reflections on the design of contextual learning and teaching materials. Retrieved from 20 July 2019, http://www.phy.cuhk.edu.hk/contextual/ approach/tem/reflect_e.html.

Souviney, R. J. (1989). Learning to teach Mathematics. London: Merrill Publishing Company.

Şensoy, Ö., \& Gökçe, S. (2017). Yaşam temelli öğrenme yaklaşımının öğretmen adaylarının başarı ve motivasyonları üzerine etkisi. The Journal of Academic Social Science Studies, 56(3), 37-52. Doi. 10.9761/JASSS6997

Taşkın, D., Aydın, F., Akşan, E., \& Güven, B. (2012). Ortaöğretim öğretmen adaylarının problem çözmeye yönelik inanç ve öz-yeterlilik algıları ile rutin ve rutin olmayan 
problemlerdeki başarıları arasındaki ilişkinin incelenmesi. e-Journal of New World Sciences Academy NWSA, 7(1), 50-61.

Tekbıyık, A., \& Akdeniz, A. R. (2010). Bağlam temelli ve geleneksel fizik problemlerinin karşılaştırılması üzerine bir inceleme, Necatibey Eğitim Fakültesi Elektronik Fen ve Matematik Ĕ̈itimi Dergisi, 4(1), 123-140.

Trimmer, W., Laracy, K., \& Love-Gray, M. (2009). Seeing the bigger picture through contextbased learning. Retrieved from 15 September 2018,

https://www.researchgate.net/publication/264240030_Seeing_the_bigger_picture_thr ough_context_based_learning

Tural, G. (2012). The process of creating context based problems by teacher candidates. Procedia-Social and Behavioral Sciences, 46, 3609-3613. Doi: 10.1016/j.sbspro.2012.06.114

Vidic, A. D. (2015). First-year students' beliefs about context problems in mathematics in university science programmes. International Journal of Science and Mathematics Education, 13(5), 1161-1187. Doi: 10.1007/s10763-014-9533-1

Yam, H. (2005). What is contextual learning and teaching in physics? Retrieved from 26 December 2018, http://www.phy.cuhk.edu.hk/contextual/approach/tem/brief_e.html

Yang, D. C. (2006). Developing number sense through real-life situations in school of Taiwan. Teaching Children Mathematics, 13(2), 104-110.

Yang, D. C., \& Wu, W. R. (2010). The study of number sense realistic activities integrated into third-grade math classes in Taiwan. The Journal of Educational Research, 103(6), 379-392.

Yang, D. C., \& Liu, Y. F. (2013). Examining the differences on comparing fraction size for $5^{\text {th }}$ graders between contextual and numerical problems. Asian Journal of Education and e-Learning, 1(2), 112-117.

Yenilmez, K. (2010). İlköğretim öğrencilerinin problem türlerini belirleme düzeyleri. Sakarya Üniversitesi Ĕ̆itim Fakültesi Dergisi, 19(1), 124-137

Yu K-C, Fan S-C., \& Lin, K-Y. (2014). Enhancing students' problem-solving skills through context-based learning. International Journal of Science and Mathematics Education, 13(6), 1377-1401

Young (2005). The contextual approach to teaching. Retrieved from 29 December 2018. http://www.phy.cuhk.edu.hk/contextual/approach/tem/talk_e.html

Wernet, J. L.W. (2015). What's the story with story problems? Exploring the relationship between contextual mathematics tasks, student engagement, and motivation to learn mathematics in middle school (Doctoral dissertation). Michigan State University, United States of America

Westera, W. (2011). On the changing nature of learning context: Anticipating the virtual extensions of the world. Educational Technology \& Society, 14(2), 201-212.

Widjaja, W. (2013). The use of contextual problems to support mathematical learning. Indonesian Mathematical Society Journal on Mathematics Education, 4(2), 157-168.

Wyndhamn J., \& Säljö R. (1997). Word problems and mathematical reasoning-A study of children's mastery of reference and meaning in textual realities. Learning and Instruction, 7(4), 361-382. 